\title{
Recently Discovered Basilosaurid, Baluchithere Rhinoceros, Horses, Sea Cow, Proboscidean, Eucrocodile, Pterosaurs, Plesiosaur, Fishes, Invertebrates and Wood Fossils, Tracks and Trackways of Dinosaurs from Pakistan; Comparison of Recognized Four Titanosaur Taxa of Indo-Pakistan with Madagascar
}

\author{
Muhammad Sadiq Malkani \\ Geological Survey of Pakistan, Muzaffarabad, Azad Kashmir, Pakistan \\ Email: malkanims@yahoo.com
}

How to cite this paper: Malkani, M.S. (2019) Recently Discovered Basilosaurid, Baluchithere Rhinoceros, Horses, Sea Cow, Proboscidean, Eucrocodile, Pterosaurs, Plesiosaur, Fishes, Invertebrates and Wood Fossils, Tracks and Trackways of Dinosaurs from Pakistan; Comparison of Recognized Four Titanosaur Taxa of Indo-Pakistan with Madagascar. Open Journal of Geology, 9, 919-955.

https://doi.org/10.4236/ojg.2019.912098

Received: October 10, 2019

Accepted: November 19, 2019

Published: November 22, 2019

Copyright $\odot 2019$ by author(s) and Scientific Research Publishing Inc. This work is licensed under the Creative Commons Attribution International License (CC BY 4.0).

http://creativecommons.org/licenses/by/4.0/

\begin{abstract}
Recent Geological and Paleontological exploration during the start of new/third millennium (from 2000 to 2019) yielded 45 taxa of vertebrates and invertebrates from Mesozoic and Tertiary (except a jawless fish from Cambrian and a trilobite from Permo-Triassic boundary) strata of Pakistan like dinosaurs, mesoeucrocodiles, eucrocodiles, pterosaurs-light bodied flying reptiles, plesiosaurs-broad bodied and ichthyosaurs-streamlined bodied reptiles and fishes, basilosaurid whale, Baluchithere rhinoceroses and paleo-horses mammals, invertebrates (hippurites/rudists, oysters, mussels and other bivalves, ammonites, belemnites nautilides and gastropods Mollusca, starfish echinoids, nummulites, assilina and alveolina foraminifers, arthropods and corals), algae, sponge and wood fossils. Here described new fossil records would attract widespread interests.
\end{abstract}

Keywords

Recent Geological and Paleontological Exploration, Biota, Pakistan

\section{Introduction}

The Recent Geological and paleontological exploration during the start of new/ 
third millennium (from 2000 to 2019) yielded more than 3000 fossils from Pakistan assigned to 45 taxa of biota. Large figures of recently discovered biota are available on research gate. Some of these biota are being described here.

\section{New Basilosaurid from Balochistan Province, Pakistan}

Systematic paleontology of Sulaimanitherium dhanotri is as follows:

Mammalia Linnaeus [1];

Cetacea Brisson [2];

Archaeoceti [3];

Basilosauridae [4];

Sulaimanitherium [5];

Sulaimanitherium dhanotri [5];

(Figure 1, Figure 2).

Sulaimanitherium dhanotri holotypic vertebral column and a few small pieces of limb elements found in the Middle Eocene (about 40 Million years ago) Drazinda shale of Kahan Group from Zamri type locality, Drug Tehsil, Musakhel district of Balochistan. The Drazinda Formation consists of marine green to grey shale in the lower and middle portion (host of Sulaimanitherium), however the upper part is chocolate to maroon. The fossils are hosted by the museum of Geological Survey of Pakistan in Quetta. Genus name Sulaimanitherium is honoring the host Sulaiman Range. Species name $S$. dhanotri honoring the tribe name of the M. Shahid Ishaq Dhanotr who collected these fossil bones.

\subsection{Diagnosis of Sulaimanitherium dhanotri Basilosauridae}

Sulaimanitherium dhanotri shares with the Basilosauridae as the long lumbar vertebrae because the other older cetaceans pakicetids, ambulocetids, remingtonocetids, protocetids and dorudontids bear short posterior thoracic, lumbar and anterior caudal vertebrae. Sulaimanitherium dhanotri characterized by the following features. Sulaimanitherium dhanotri have relatively more deep, stocky and less elongated lumbar centra while Basilosaurus cetoides have shallow, slender and more elongated lumbar centra. Sulaimanitherium dhanotri lumber centra are less elongated than Basilosaurus drazindai and Basilosaurus isis. Sulaimanitherium dhanotri lumber centra are more elongated than Basiloterus hussaini. Sulaimanitherium dhanotri lumber centra are transversely more thicker than Basilosaurus drazindai and Basiloterus hussaini. Sulaimanitherium dhanotri have two recessed vascular fenestrae divided by one thin bony septa or partition located in a deep central concavity on the ventral and also dorsal surfaces of lumbar centra while Basiloterus hussaini [6] from Pakistan have three recessed vascular fenestrae divided by thin bony partitions in the ventral concavity. Sulaimanitherium dhanotri have relatively less longer, less deeper and more thicker lumbar centra than Basilosaurus drazindai lumbar centra of about same position. Sulaimanitherium dhanotri have possibly three fenestrae forming triangle in the core of radial rugosities on anterior view of lumbar centrum, while 
Basilosaurus drazindai and Basiloterus hussaini lack these three fenestra. Roots of the transverse processes oriented on the mid of lateroventral margin in $\mathrm{Su}$ laimanitherium dhanotri while transverse process arise in the anterolateral margin of the vertebral body of Basilosaurus drazindai [6]. Transverse process of Sulaimanitherium dhanotri is relatively considerably anteroposteriorly less long at the base than the transverse process of Basilosaurus drazindai. As usual in archaeocetes, the pedicles arise closer to the anterior end of the centrum than to the posterior end of Basilosaurus drazindai [6] while in Sulaimanitherium dhanotri the pedicles are found in the mid centre (centrally oriented or feebly close to anterior termination of centrum. Neural canal of Sulaimanitherium dhanotri is transversely less broad than Basilosaurus drazindai while the lumbar centra are thicker in Sulaimanitherium dhanotri than Basilosaurus drazindai. Cervical centra have strongly ventrally reduced surface. Ventrally reduced surface of cervical centrum is laterally bounded by two ventral keel (one on each side). The cervical centra forms hexagonal wedge shape, two faces on left lateral and two faces on right lateral and one ventral reduced face and one dorsal surface which is base of neural canal.

\subsection{Description of Sulaimanitherium dhanotri Basilosauridae}

100 holotypic specimens belonging to more than forty vertebrae including cervical, thoracic, lumbar and caudal vertebrae and more than fifty cross sections of ribs, appendicular bones, transverse processes, neural spines, etc. (Figure 1) (Figure 2). These fossils are found as about $10-12 \mathrm{~m}$ long belt on marine green shale showing associated nature and further there is no duplication and size are same, showing the one individual holotypic animal. The recognizable specimens include 5 cervical vertebrae, 3 or more thoracic, 5 or more lumbar and 3 or more caudal vertebrae which provide facility for description and show a number of important diagnostic landmarks that are best studied in comparison with other basilosaurids. These vertebrae are distinctive in the size, centrum proportions and morphology. The cervical vertebrae include almost complete series (Figure 1). The middle and lower part of the atlas (first cervical vertebra) is preserved and has a very thin vertebral circular body forms and consists of lower and middle parts forming ring shape around the foramen magnum. Atlas centrum is shallow and broadest for adjustment of occipital condyles. The atlas vertebra (centrum with pedicle and neural arch) is subcircular shaped vertebra. The neural canal is generally round, and may be the same size as the foramen magnum. The ventral face is very broad than all other cervicals. Neural canal in atlas seems to be relatively broader than the following cervicals. The dens or odontoid process is destroyed in the axis body.

The cervical vertebral body (centrum) is broad with low height and dorsoventrally compressed. The cervicals (except atlas) and probably anterior thoracic have wedge-shaped. The cervical centra have strongly ventrally reduced surface. The ventrally reduced surface is laterally bounded by two ventral keel (one on 


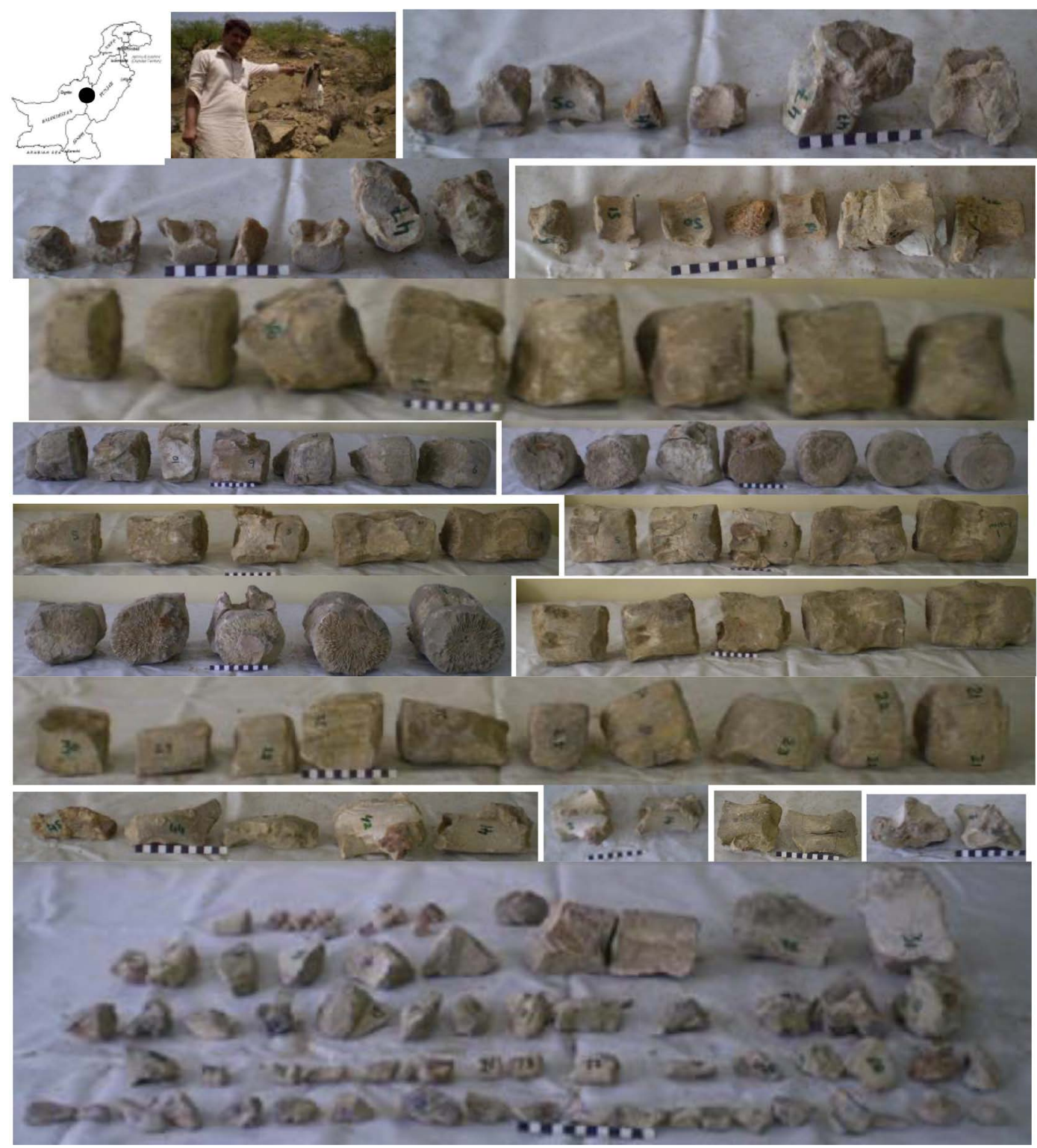

Figure 1. Sulaimanitherium dhanotri holotype fossils. Row 1, Map of Pakistan showing Zamri type locality; right man pointing left man standing on host locality; seven cervical vertebrae MSID-52, 51, 50, 49, 48, 47, 46 in lateral view. Row 2, seven cervical vertebrae MSID-52, 51, 50, 49, 48, 47, 46 in ant/posterior and ventral views. Row 3, thoracics and lumbar vertebrae MSID-20, 19, 18, 17, 16, 15, 14, 13. Row 4, thoracic and lumbar vertebrae MSID-12, 11, 10, 9, 8, 7, 6. Row 5, 6, lumbar vertebrae MSID-5, 4, 3, 2, 1. Row 7, caudal vertebrae MSID-30, 29, 28, 27, 26, 25, 24, 23, 22, 21. Row 8, neural canal filled mud cast with pedicle and neural arch MSID-45, 44, 43, 42, 419 (photo 1) and MSID 42, 41 (photo 2, 3, 4). Row 9, pieces of neural arches, ribs and limbs in 5 subrows. Subrow 1, some un-numbered pieces; Subrow 2, MSID-40 to 31; Subrow 3, MSID-65 to 53; Subrow 4, MSID-80 to 66; Subrow 5, MSID-100 to 81. Scale each black or white digit is 1 centimeter $(\mathrm{cm})$.

each side). The cervical centra forms hexagonal wedge shape, two faces on left lateral and two faces on right lateral and one ventral reduced face and one dorsal surface which is the base of neural canal. The vertebral body and pedicle and along with neural arch forms the dorsoventrally oval shape. The ventral face is reduced and laterally bounded by keel on each side (on left lateral and on right 
lateral sides). Then the lower lateral face is started as inclined laterodorsally and then it forms a lateral keel ridge and then dorsal lateral surface is converged (on both sides) toward the neural canal and last face is represented by horizontally straight face and it forms the base of neural canal. The vertebral body or centrum maximum width is $5 \mathrm{~cm}$, height is about $3 \mathrm{~cm}$ (up to ventralmost part of neural canal) and length without epiphyses is $5 \mathrm{~cm}$. The epiphyses are well preserved in two vertebrae. Ventrally the cervical centra have reduced plane surface. This ventral plane surface is anteroposteriorly elongated. This surface is laterally bound by lateral inclined surface. There is a pair of ventral keel, each is located on the contact of reduced ventral and inclined lateral surface. Dorsally the cervical centra are horizontal for the inset of neural canal. The lateral surface is inclined plane which dorsally joined the pedicle. The anterior and posterior articular surfaces are set obliquely. It has multi-angled curved form of centra alongwith anterior and posterior surfaces. The measurement of faces in one centrum are as follows; the ventral horizontal plane is narrow (2 $\mathrm{cm}$ transversely wide) and long ( $5 \mathrm{~cm}$ anteroposteriorly long), then inclined lateral surface started in dorsolaterally direction and its height or depth is $5 \mathrm{~cm}$ from base (laterally equal to horizontal plane) to the upper point (central axis of neural canal) and $5 \mathrm{~cm}$ anteroposteriorly long. The central part of ventral surface is flat longitudinally. The pedicle of cervical centra is thick up to $2 \mathrm{~cm}$ and cover anteroposteriorly all dorsal surface of centrum. The neural arch has robust postzygapophysis which seems to be not extended beyond centrum. The neural canal of cervical centrum is deep, generally forming subcircular to dorsoventrally suboval shape. In one vertebra the diameter of neural canal is about $3.5 \mathrm{~cm}$ transversely and $4 \mathrm{~cm}$ dorsoventrally. The transverse processes including diapophysis are laterally oriented in the cervical found on the anterior epiphysis of cervical centra. The transverse processes are preserved on the anterior epiphysis of cervical vertebrae. As a whole cervical vertebrae are tall. The centra are broad. The neural canals are deep. Further neural canal is tall or deep in all cervical except anteriormost one or two cervicals. In this regards the cervical vertebrae of Sulaimanitherium dhanotri matches closely with cervicals of Zygorhiza kochii [7].

The thoracic centra are relatively shorter than lumbar and longer than cervicals. Thoracic centra are tall than cervical centrum but almost equal to lumbars. Thoracic centra are more wide than cervical centrum but almost equal to lumbars. The transverse processes are situated more dorsally on the vertebra body than lumbars. The transverse processes are lateroventrally (started from mid height of centra) oriented in the a few last thoracics. The centra are slightly broad. Its width is slightly more than height. The height and width almost remain constant in lumbars while length is higly increased. The cranial epiphysis is suboval. The transverse process is triangular to subcircular and thicker dorsoventrally and oriented on the lateral sides of thoracic centra. The epiphysis are massive (not spongy) and porcellaneous type. The epiphysis show ring structure development. These are recognized by the triangular to subrounded shaped 
transverse process located on the lateral sides of the vertebral bodies. The vertebral bodies have width, depth and length more than cenvical and less than lumbars.

The lumbar centra are anteroposteriorly elongated and transversely oval to suboval shaped. The height and width are almost same as in thoracic, but slightly more than anterior caudals. The ventral position and downward trend of transverse process of this vertebra shows its assignment to lumbar because in dorsal position is more dorsally oriented [8]. One longest preserved centrum of Sulaimanitherium dhanotri is 27 centmeter $(\mathrm{cm})$ long and $17 \mathrm{~cm}$ wide and $13 \mathrm{~cm}$ high while the Basilosaurus drazindai have different proportion like $30 \mathrm{~cm}$ long, $17 \mathrm{~cm}$ wide and $14.5 \mathrm{~cm}$ high and Basiloterus hussaini have also different proportion like $20 \mathrm{~cm}$ long, $15 \mathrm{~cm}$ wide and $13.3 \mathrm{~cm}$ high. Sulaimanitherium dhanotri have relatively less long, less deep and more thicker lumbar centra than Basilosaurus drazindai lumbar centra of same position. The lumbar centra of Sulaimanitherium dhanotri is relatively less elongated than Basilosaurus drazindai and Basilosaurus isis. The lumbar centra of Sulaimanitherium dhanotri is relatively more longer than Basiloterus hussaini. The lumbar centra are broad as the thoracic and cervical vertebrae. The posterior and anterior parts of centra are plain and show radial texture rugosities suturing with epiphyses. The centra are covered with radiating bony rugosities that interdigitated with the missing epiphyses. The lumbar vertebrae are feebly waisted due to incursion of two ventral fenestrae. Further the lumbar centra are slightly dorsoventrally narrow in the middle of the centrum while anterior and posterior portion of centra is relatively high. The central or sagital ventral keel is not found in any thoracic and lumbar vertebrae but two ventral keels are found in cervicals. Anterior epiphysis or end plate is present in a few vertebrae. Ring structure found on anterior/posterior face of centrum epiphysis. The dorsal and ventral surfaces of centra are not flat but have mid concavities in the ventral and dorsal surfaces. The dorsal surface of centra mostly resemble with the ventral surface, only difference is the ventrally two long and thick vascular fenestrae/foramina/vascular canal and dorsally two relatively shorter, circular and thin fenestrae. These fenestrae typically perforates basilosaurid vertebrae. The mid-dorsal and ventral surfaces show moieties/equal parts/mirror images. There are two rounded vascular fenestrae (left and right vascular fenestrae which are separated by a central thin bony lamina) between the pedicles in Sulaimanitherum dhanotri while only one rounded vascular fenestra is reported in Basilosaurus isis from Jordan [9]. Between left and right transverse process there is a pair of conspicuous, anteroposteriorly elongated oval-shaped, transversely narrow opening fenestrae for the dorsoventral vascular canal. There are two vascular fenestrae (left and right vascular fenestrae which are separated by one central thin bony lamina) in Sulaimanitherum dhanotri which are anteroposteriorly elongated on ventral surface, and rounded on dorsal surface, while three vascular fenestrae separated by bony partitions ( 2 central thin bony laminae) are reported in Basiloterus hussaini [6] 
from Pakistan. The vertebra has a broad, shallow, smooth groove on each side and these broad grooves continue dorsally in the centrum. The sediments filled the dorsoventral vascular canals.

As usual in archaeocetes, the pedicles arise closer to the anterior end of the centrum than to the posterior end of Basilosaurus drazindai [6] while in Sulaimanitherium dhanotri the pedicles are found almost in the mid centre (centrally oriented or feebly close to anterior termination of centrum) of centrum. The pedicles measure upto $11 \mathrm{~cm}$ in length anteroposteriorly and $4.5 \mathrm{~cm}$ in width mediolaterally at the base, and it is located in the middle of centrum. Sulaimanitherium dhanotri has centrally oriented thick pedicles upto $4.5 \mathrm{~cm}$ while Basilosaurus drazindai have relatively thin pedicles upto $3 \mathrm{~cm}$ thick transversely while their anteroposterior lengths are almost same. The pedicle and neural arch cover all along the dorsal length of cervical centra. The neural arch is dorsally broken but its broken surface show that the neural spine is anteroposteriorly long and located in the central longitudinal axis (sagital axis) and posteriorly it becomes thick and approached close to the postzygapophyses (or its remnant). The pre-zygapophysis seems to be relatively low but completely not preserved. The left or right postzygapophyses of Sulaimanitherium dhanotri are thicker elements than Basilosaurus drazindai. The postzygapophyses are preserved posteriorly at the level of preserved neural canal.

The transverse width of neural canal anteriorly about $9 \mathrm{~cm}$ and posteriorly about $9.5 \mathrm{~cm}$ of Sulaimanitherium dhanotri while it is anteriorly $11 \mathrm{~cm}$ and posteriorly $11.5 \mathrm{~cm}$ of Basilosaurus drazindai. The neural canal of Sulaimanitherium dhanotri is transversely less broad than Basilosaurus drazindai while the lumbar centra are thicker in Sulaimanitherium dhanotri than Basilosaurus drazindai. The neural canal/cerebral canal of a few vertebrae are preserved perfectly as filled mudstone (Figure 2). The neural canal is a thick, broad and wide canal which is ventrally bifurcated centrally by embedded mid dorsal keel in centra. The bifurcated neural canal is partially subdivided into left and right neural subcanal. At fenestra level the neural canal is relatively more deep and convexing showing connection with the vascular anal. The lateral surface of neural canal is rounded. The dorsal part of neural canal represents sagital anteroposteriorly elongated keel formed by fellow neural arches. The posteriormost part of neural canal is formed by three dorsal keels or crests, one major crest at sagital while other smaller one crest on both left and right limb/flanks. Anteriormost part of neural canal show only one dorsal crest or keel on sagital line.

The transverse process of Sulaimanitherium dhanotri and Basilosaurus drazindai have considerably different proportions and also different positions. The roots of the transverse processes oriented on the mid of lateroventral margin in Sulaimanitherium dhanotri while transverse process arise in the anterolateral margin of the vertebral body of Basilosaurus drazindai [6]. The transverse process of Sulaimanitherium dhanotri at base have anteroposterior length $12 \mathrm{~cm}$ and width $4 \mathrm{~cm}$, while Basilosaurus drazindai at base have anteroposterior 


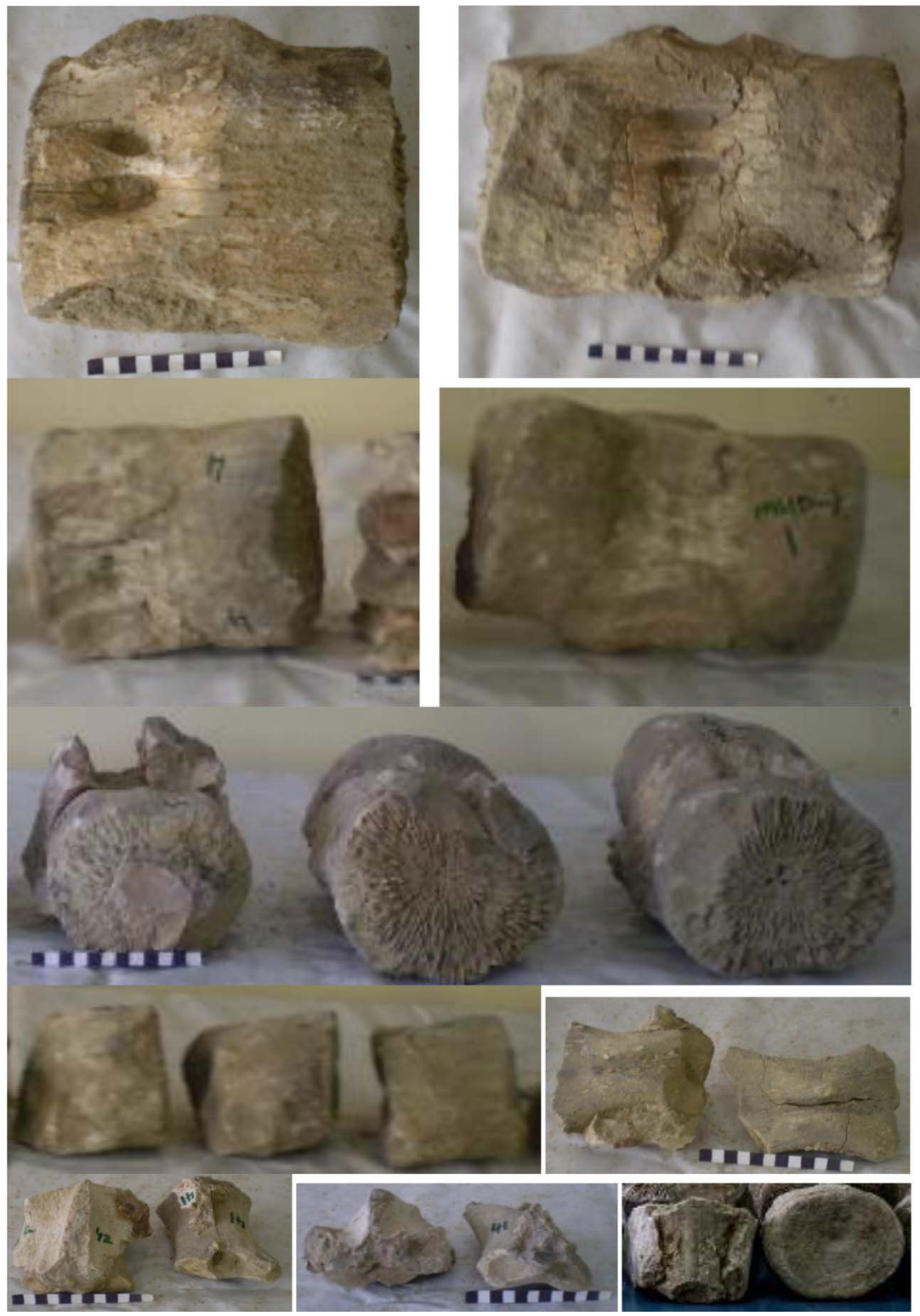

Figure 2. Sulaimanitherium dhanotri holotype. Row 1, lumbar vertebrae (MSID-4, MSID-1) in ventral view showing elongated fenestrae and relatively less long and mid oriented transverse process. Row 2, lumbar vertebrae (MSID-4, MSID-1) in dorsal view with two circular and small fenestrae, and relatively less long pedicles. Row 3, lumbar vertebrae (MSID-3, MSID-2 MSID-1) with partial epiphysis in one centrum and rugose structure in other two centra in ant/posterior views. Row 4, thoracic vertebrae (MSID-16, MSID-15, MSID-14) showing triangular to subrounded transverse process located in lower half of centra; 2 neural canal natural mud cast with neural arch bones in ventral views (MSID-42, MSID-41). Row 5, p1, 2 neural canal natural mud cast with neural arch bones (MSID-42, MSID-41) in 2 views; $\mathrm{p}$, dorsal view of vertebrae with neural canal cast having anteroposteriorly long dorsal keel (right), and ring forming structural lineation on epiphysis ant/posterior view (left). Scale, each black or white digit is $1 \mathrm{~cm}$.

length $15.5 \mathrm{~cm}$ and $4 \mathrm{~cm}$ in width. In this way the transverse process of Sulaimanitherium dhanotri is relatively considerably less long than the transverse process of Basilosaurus drazindai. 
No any sacral (fused and coosified vertebrae between the caudal and lumbar vertebrae) are not found. The supposed caudal vertebrae are considerably relatively less long than lumbar. No large limb bones are found only small cross section are found. Sulaimanitherium dhanotri has subtriangular transverse process on moderately long distal thoracic while Chrysocetus fouadassii [7] from Morocco have anteroposteriorly elongated oval or elliptical shape on short distal thoracics. The Sulaimanitherium dhanotri has relatively large and long lumbar vertebrae while Platyosphys aithai have relatively short lumbars. Further the transverse process of lumbar vertebrae of Sulaimanitherium dhanotri are relatively anteroposteriorly short (less elongated) while Platyosphys aithai have relatively anteroposteriorly long transverse process of lumbar vertebrae. The Sulaimanitherium dhanotri have centrally oriented transverse process (anteroposteriorly located in the centre ventral margin of lateral sides while the Eocetus schweinfurthi of southwestern Morocco and Eocetus drazindai (Basilosaurus drazindai) of Pakistan have anteriorly oriented transverse process. Further the length of lumbar centrum of Sulaimanitherium dhanotri is relatively less than the Eocetus drazindai of Pakistan. B. cetoides lumbar and distal thoracic centra are slender and elongated (height is less and length is high) while Sulaimanitherium dhanotri have relatively less elongated and more deep (high) centra. Basilosaurus is the first Archaeoceti named by [10]. Sulaimanitherium dhanotri is among the largest Basilosauridae.

\section{New Baluchithere Rhinoceros from Balochistan Basin}

Systematic paleontology of Pakitherium shagalai is as follows:

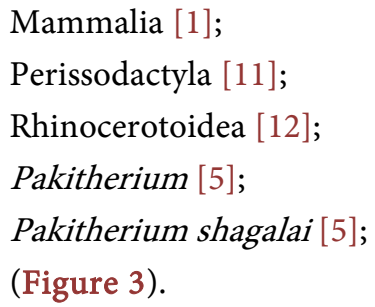

Pakitherium shagalai new genus and new species based on cranial and postcranial skeleton found from the Early Eocene Shagala formation (terrestrial red mud and sandstone bone bearing; 50 - $45 \mathrm{Ma}$ ) of Shagala Group of Shagala type locality (which is $12 \mathrm{~km}$ northwest of Shagala town), Kamardin Kareez, Zhob district, Balochistan. These bones are hosted in museum of Geological Survey of Pakistan in Quetta. Genus name Pakitherium honoring the host country Pakistan and therium for beast. Species name $P$. shagalai honors the host Shagala formation, area and town. Pakitherium shagalai shared with baluchithere giant rhinoceros Rhinocerotoidea on the basis of enormous thick and relatively less long lower canine (tusk like), the huge and gigantic size and shape of limb bones and ribs. Pakitherium shagalai characterized by enormous thick root with relatively less long tapering canine like incisor (tusk like) with lateral keel and subcircular cross section and thick and huge postcranial skeleton. Further this inci- 
sor is relatively less thick and less long (tapering) which is different from more long and more thick incisor of Buzdartherium gulkirao. The new genera Buzdartherium from Sulaiman basin (which is also host of Paraceratherium and Baluchitherium) and Pakitherium first time from Balochistan basin based on cranial and postcranial skeletons and can help for correlation with Paraceratherium cranium and Baluchitherium postcranial skeleton from Pakistan.

Twenty seven (MSID-201 to MSID-227) holotypic cranial (tusk/canine like thick and long tooth) and postcranial skeleton like centrum, a pair of proximal metapodial, a pair of distal ribs, cross section of leg bone and many cross section of alae processes, ribs, neural spines, etc belonging to one individual due to close finding and size matching and no duplication. The canine like $1^{\text {st }}$ incisor root is much thick, stout and massive while tapering crown show black/dark grey enamel (Figure 3). Its cone is blunted/partially broken but its large diameter and massive root morphology show its position as $1^{\text {st }}$ incisor of lower jaw. The broken end of crown show green/light green materials. This lower incisor is directed forward. The preserved length of crown is $6 \mathrm{~cm}$. The lateral maximum diameter at the base of crown is $5 \mathrm{~cm}$ and anteroposterior diameter is $6 \mathrm{~cm}$. This incisor show lateral keel. The root is much thicker and representing for its position as $1^{\text {st }}$ incisor (or may be forward pointing lower tooth). This incisor presents high specialization. The partial centrum may belong to thoracic vertebra. One lateral side of the wedge shape centrum is preserved and remaining portion is broken. The preserved posterior/anterior articular surface is slightly inclined. The ventral surface is partially preserved. The central part of ventral surface is smooth horizontal. Lateral sides incline dorsolaterally and its length of ventrodorsal inclined height is $4.5 \mathrm{~cm}$. This centrum resembles closely with the Baluchitherium thoracic centra. However the size and inclinations are also different suggesting different genus. The distal parts of a pair of ribs which show huge sizes and thickness. The width and depth of preserved rib are $6 \mathrm{~cm}$ and $4 \mathrm{~cm}$, and preserved length is $15 \mathrm{~cm}$ (Figure 3). These distal ribs are not plain but show little concavo-convexo feature. One cross section of limb bone most probably radius or may be fibula diaphysis is also found. This cross section is tapering rapidly on one side than on other side (Figure 3). The collected bone is only diaphysis and proximal or distal epiphyses are damaged because in adult the proximal and distal epiphyses are fused with diaphysis. On the preserved proximal part its maximum dimensions/diameters are $9 \mathrm{~cm}$ and $6 \mathrm{~cm}$ which also show oval shape diaphysis. The distal part show dimensions of $7 \mathrm{~cm}$ and $5 \mathrm{~cm}$ and also oval shape. The surface is smooth. The cortical (outer) part of the diaphysis is less than 1 $\mathrm{cm}$. The proximal metacarpals show swollen proximal part. Further its shaft is greatly reduced from proximal swollen part. The maximum dimensions at proximal end are $12 \mathrm{~cm}$ and $8 \mathrm{~cm}$. The proximal part of metacarpal show biconcavity on articular surface, both cochleae are biconcave. One cochlea is much greater than other (Figure 3). A pair of very small femora (MSID-228, MSID-229) is also found in association with holotype animal in the same site and same forma- 
tion show last stage pregnancy and may belong to son/daughter of Pakitherium shagalai mother. The femur expands less toward the proximal end. The femur head is ball like. There are two tuberosities/trochanters on the anterior and posterior side of proximal femur just close to femur head. Dorsally the head and other part of proximal femur show slight convexing arc shape. It may belong to embryo babe/child of Pakitherium shagalai. What is the reason for the death of both mother and her babe/child? However their association shows the daughter/son in mother belly due to pregnancy in Pakitherium shagalai. Further the size and development of femora show the middle to late stage embryo developments.

\section{New Baluchithere Rhinoceros from South Punjab}

Systematic paleontology of Buzdartherium gulkirao is as follows:

Mammalia [1];

Perissodactyla [11];

Rhinocerotoidea [12];

Buzdartherium [13] [14];

Buzdartherium gulkirao [13] [14];

(Figure 3).

Buzdartherium gulkirao a new genus and species based on tusk like incisor tooth, premolar tooth, tooth cross section, vertebrae, ribs, spines, proximal humerus, ulna, proximal pubis, pubis cross section, proximal ischium, ischium cross section, femur, carpal/astragalous/tarsal, metacarpal/metatarsal, phalanges, and ungual/toe with some bone pieces (Figure 3) collected from ferruginous conglomeratic beds (just below the $5-10 \mathrm{~m}$ thick silica sand beds) of Oligocene Chitarwata Formation in Taunsa-Gulki section of Dera Ghazi Khan District (Punjab). The etymology of Buzdartherium honor the Buzdar tribe and species name B. gulkirao honor the Gulki locality and Rao M. Ayub-with his kind cooperation this discovery was made. The fossils are hosted in the Museum of Geological Survey of Pakistan, Quetta. Buzdartherium gulkirao shared with Rhinocerotoidea on the basis of enormous thick and long canine (tusk like) like incisor, the huge and gigantic size and shape of ribs and limb bones. Buzdartherium gulkirao characterized by enormous thick and oval shaped cross section of long canine (tusk like) like incisor which externally hosts the subparallel keel like polished fibrous, dorsoventrally elongated structures, oval shaped premolar and sickle shaped large ungula. The close occurrence, relevant sizes and no duplication of thirty seven holotypic specimens MSM-1-Taunsa to MSM-37-Taunsa, tells their association with one individual. The canine like $1^{\text {st }}$ incisor root is much thick and massive while crown show light brown enamel. Incisor tooth is stout and long. Its cone is broken but its large diameter and massive root morphology show its position as $1^{\text {st }}$ incisor. This incisor presents high specialization and includes parallel keel like fibrous dorsoventrally elongated structures on polished enamel external surface. The first cheek tooth is collected which have oval 


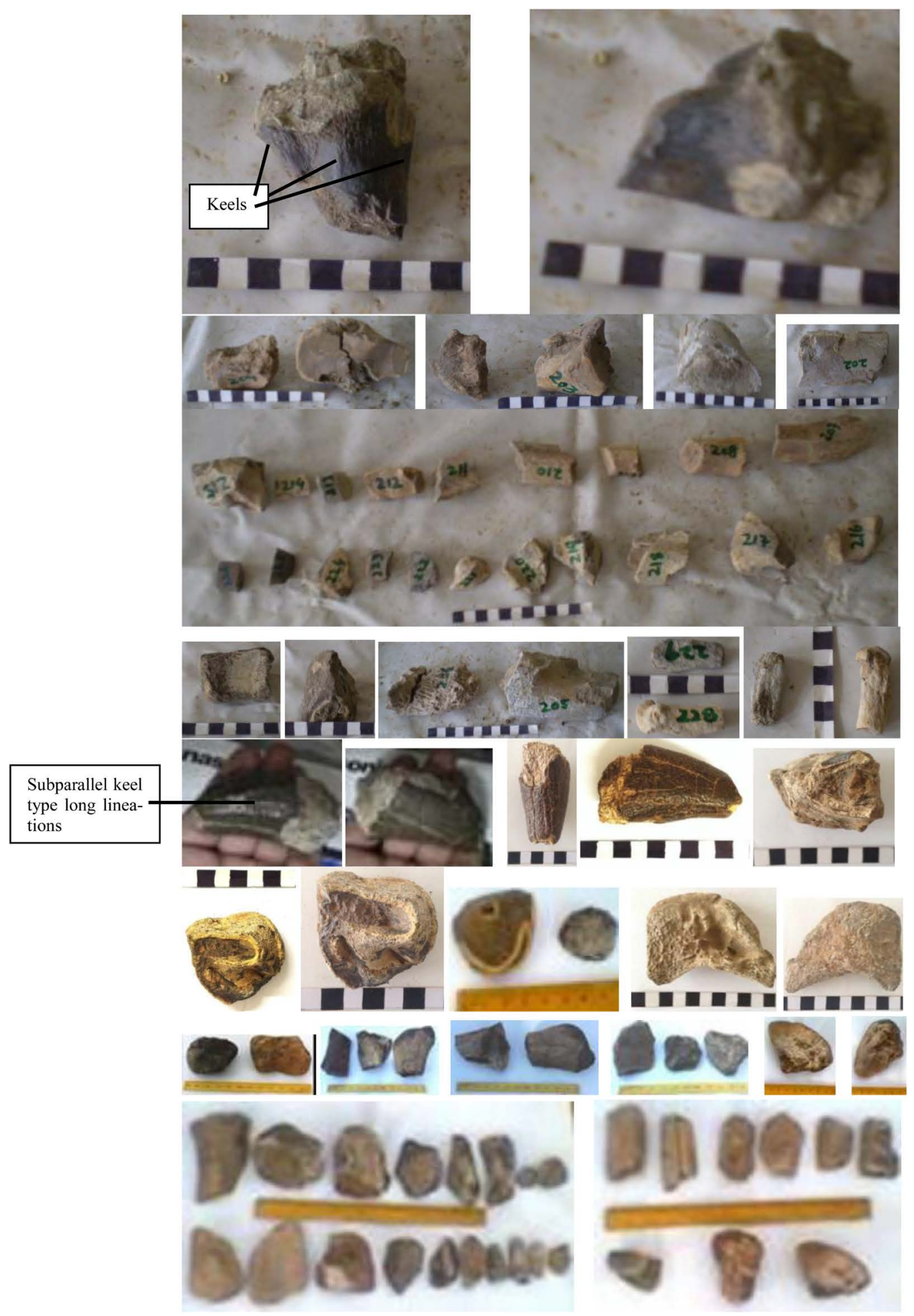

Figure 3. Baluchithere Rhinoceros fossils. Row 1 to 4, (except last 2 photos which showed referred baby fossils), Pakitherium shagalai type locality and holotypic fossils. Row 1, lower incisor MSID-201 in 2 views. Row 2, 3, 4, postcranial elements. Row 5 to 8, Buzdartherium gulkirao type locality and holotypic fossils. Row 5, large incisor MSM-1-Taunsa in 4 views; lower incisor MSM-50-Taunsa. Row 6, molar MSM-2/3-Taunsa in 3 views; molar MSM-4-Taunsa; lacrimal MSM-51-Taunsa in 2 views; Row 7, 8, most specimens of postcranial and only a few specimens of cranial skeleton. Scale each black or white digit is $1 \mathrm{~cm}$. Yellow full scale bar is $30 \mathrm{~cm}$. 
shaped. One partial centrum may belong to thoracic region with $14 \mathrm{~cm}$ preserved length. The preserved posterior/anterior articular surface of centrum with plano-convexo structures is partially eroded and seems to be set obliquely. The other fragment of centrum have no central hollow cavity. The ribs are thick and large again show its assignment to huge rhinoceros. The rib has two facets for articulating with vertebrae. The rib cross section is nearly plain on one side while convexing in other side and convexing line set obliquely from middle to outer side. One curved plate having a head like tuberosity $(3 \mathrm{~cm}$ high, $7 \mathrm{~cm}$ wide and $10 \mathrm{~cm}$ long) may belong to proximal humerus. The other plate $(11 \mathrm{~cm}$ width and preserved length is also $11 \mathrm{~cm}$ ) may belong to part of ilium and acetabulum because plate has groove like acetabulum. The proximal pubis/ischium has a concave groove for acetabulum or for the adjustment of femur. An oval cross section of pubis/ischium is also collected which shows $4 \mathrm{~cm}$ thick and $9 \mathrm{~cm}$ wideness, the length preserved is about $10 \mathrm{~cm}$. A proximal ulna having half lunate type preserved groove $(11 \mathrm{~cm} * 8 \mathrm{~cm})$ for adjustment of humerus condyle and some olecranon part is preserved. Dorsally it is triradial. Ulnar cross section have central hollow of $4 \mathrm{~cm}$ in dia. The peripheral bone is $1 \mathrm{~cm}$ to $2.5 \mathrm{~cm}$ thick. A proximal femur with its head $(8 \mathrm{~cm})$ is also preserved. The femur expands less toward the proximal end. The femur head is a ball like. There is a prominent ridge on the posterior side just close to femur dorsal surface. Dorsally the head and other part of proximal femur are weathered. The dorsal surface of proximal femur has $14 \mathrm{~cm}$ length and width may be $10-12 \mathrm{~cm}$. The preserved length of femur is about $15 \mathrm{~cm}$. The lateral surface of femur is convex like. It has circular hollow in the centre of bone cross section and this hollow has thick peripheral bone. The hollow has $6 \mathrm{~cm}$ in dia and peripheral bone has $1 \mathrm{~cm}$ to $2.5 \mathrm{~cm}$ thick layer. The proximal pubis and ischium has a groove for acetabulum. The large size of bones, spines, manus/pes bones and associated ungual/toe show their assignment to baluchithere. The small egg like material found with this assemblage may belong the eucrocodiles or snake eggs or the osteoderms or coprolite of Rhinoceros.

\section{Early Horses (Perissodactyls) from Balochistan}

Systematic paleontology of Mirvitakri haji is as follows:

Mammalia;

Perissodactyla;

Hippomorpha;

Mirvitakri new genus;

Mirvitakri haji new species;

(Figure 4).

Mirvitakri haji, a new genus and new species of an old horse based on holotypic partial lower jaw including posterior dentary with angular process (MSM-141-4s) (Figure 4). It is found from the Latest Cretaceous terrestrial Vitakri Lameta Formation of Vitakri area, Barkhan District, Balochistan. Genus 
name Mirvitakri is honoring the Mr. Mir Muhammad Khetran of Vitakri village. Species name M. haji honoring the Haji Ahmad Khetran (field worker), of Rakhni Village, Barkhan district, and Haji Hafeez (Naib Qasid) and Haji Abdullah Jan, Haji Hameed Brohi, Haji Behram Khan and Haji Irfan (drivers) of Geological Survey of Pakistan, Quetta, Balochistan for excellent cooperation and services during most of the fieldworks in the Sulaiman and Balochistan. Holotypic specimen is housed in the museum of Geological Survey of Pakistan, Quetta. The specimen being rounded angular and long nature of dentary it is supposed to be a horse. This extinct horse seems to be small just more than a meter in length. The angular and posterior dentary formed rounded shape. The posterior dentary is transversely thin and show rounded angular profile of lower and posterior views. The preserved posterior dentary angular portion is about 6 $\mathrm{cm}$ anteroposteriorly long, $3 \mathrm{~cm}$ dorsoventrally high and transversely about $1 \mathrm{~cm}$ thick. Due to The lower back of dentary shows the rounded process emerged as angular for the attachment to upper jaw. This fossil of mammal (old horse) is the oldest in Pakistan.

Systematic paleontology of Bolanicyon shahani is as follows:

Mammalia;

Perissodactyla;

Hippomorpha;

Bolanicyon [13];

Bolanicyon shahani [13];

(Figure 4).

Bolanicyon shahani a new genus and new species previously reported as large quettacyonid [13], but now expected to be a horse due to long dentary and rounded angular. Bolanicyon shahani is based on holotypic dentary with teeth MSM-1068-Western Mach (Figure 4), found at the coal mining at depth of about $500 \mathrm{~m}$ in the Early Eocene Toi Formation of Gishtari area southwestern Mach, Bolan, Balochistan. Genus Bolanicyon is named after the Bolan river and district of Balochistan. The species name Bolanicyon Shahani honor the coal miner Gul Zaman Shahani who provided the holotypic specimen. Holotypic specimen is housed in the museum of Geological Survey of Pakistan, Quetta. Its 6 molar dentitions (Figure 4) with angular bone are well preserved while the anteriormost portion including long diastema including one canine tooth and further ahead incisors were destroyed. The teeth size increasing posteriorly. Further the transverse thickness of total preserved dentary is increasing backward or posteriorly. The preserved dentary is about $16 \mathrm{~cm}$ long and more than 1 $\mathrm{cm}$ thick and maximum thick at angular is about $2 \mathrm{~cm}$. It is a small may be about 1 meter in length and also extinct horse. This mammal (old horse or Quettacyonidae) is among the oldest in Pakistan.

\section{Kilgai Sea Cow (Protosiren, Sirenia) from Balochistan}

Systematic paleontology of Kilgai moolakharzani is as follows: 
Mammalia;

Protosirenidae;

Kilgai new genus;

Kilgai moolakharzani new species;

(Figure 4).

Kilgai moolakharzani based on holotypic typical tooth or sub tooth MSM-1065-K (Figure 4). It is found from the Early Eocene Shaheed Ghat shale of Chamalang Group (=Ghazij Group), Kil locality, Moola-Kharzan area (western Kirthar Range), Khuzdar District, Balochistan province, Pakistan. The genus name Kilgai is honoring the host Kil locality of Kharzan area, and gai in Urdu or Saraiki language mean cow. The species name $K$. moolakharzani honoring the host Moola River and Kharzan headquarter Tehsil Moola. The holotypic specimen is housed in the museum of Geological Survey of Pakistan, Quetta. Kilgai moolakharzani shared with Protosirenidae as a large circular ornamented tooth with core and outer peripheral bones interlayered by a circular cavity. Further Kilgai have ornamented circular tooth which is differentiated from all Indo-Pakistan Sirenians. Kilgai has ornamented circular tooth closely matches with the Desmostylus which have pentagonal type tooth. Kilgai extends the distribution of close relative of Desmostylus in Indo-Pakistan. It is characterized by star like network of bone in the core of circular tooth, followed by circular depression or cavity with star like outer and inner margin and then outer peripheral bone which is ornamented externally which is represented by dot like ornaments. Outer peripheral exposure of tooth has fine dot type ornamentations arranged in linear orientation trending up-down or dorsal to ventral. This typical tooth has three parts. First is the outer peripheral bone. Second part is the core network of bones shaping as star. The third part is the cavity inter layered by first and second parts of tooth. The tooth is typical and has relatively thin outer bone periphery and thick central network of bone, both interlayered by circular cavity. The diameter of tooth is $1.5 \mathrm{~cm}$ and also preserved length of tooth is $1.5 \mathrm{~cm}$.

\section{Gomphotherium buzdari Proboscidean of South Punjab}

Systematic paleontology of Gomphotherium buzdari is as follows:

Mammalia;

Proboscidea;

Gomphotherium;

Gomphotherium buzdari [13];

(Figure 4).

Gomphotherium buzdari [13], a new genus and new species of a big Proboscidean based on holotypic materials (Figure 4) like proximal femur, distal femur with its partial two condyles and proximal tibia (Figure 4) collected from Miocene Litra Formation of Vihowa group in Mahoi area, eastern limb of Zinda Pir anticline [13] [14]. The species name G. buzdari honoring the host Buzdar tribe. 


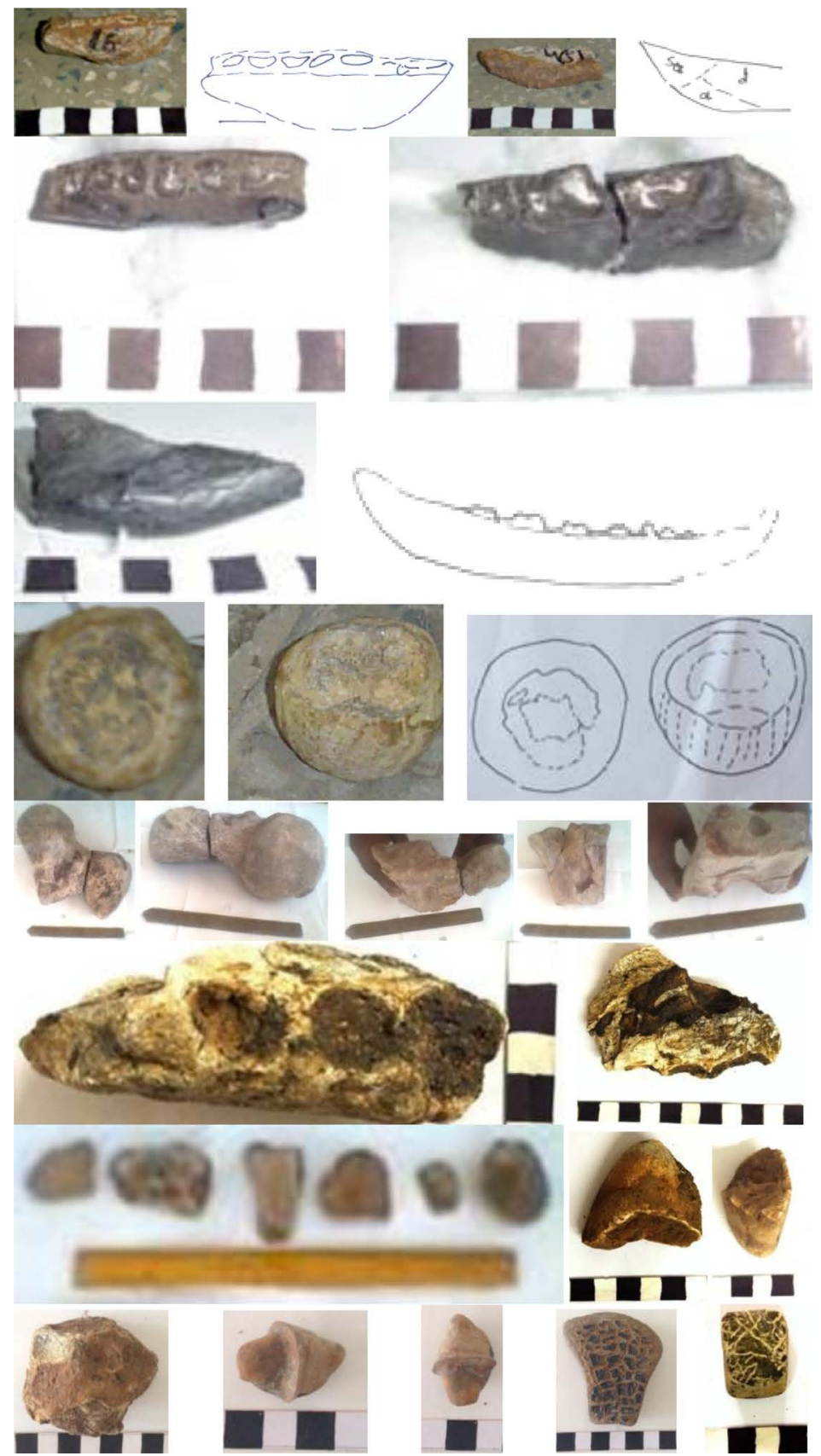

Figure 4. Row 1, p1, 2, Saraikisaurus minhui dentary with teeth MSM-157-16; p3, 4, Mirvitakri haji angular part of dentary MSM-141-4s (a-angular, d-dentary, sa-surangular). Row 2, 3, Bolanicyon shahani lower jaw with teeth and angular (MSM-1068-western Much) with line drawing. Row 4, Kilgai moolakharzani typical tooth MSM-1065-K with line drawings. Row 5, Gomphotherium buzdari holotype proximal femur (mosaic of MSM-MSID-1 and MSM-MSID-2) in 2 views; distal femur (mosaic of MSM-MSID-3 and MSM-MSID-5) and proximal tibia MSM-MSID-4 in 2 views. Row 6, 7, 8, Asifcroco retrai fossils except last one photo. Row 6, holotypic jaw (MSM-46-Taunsa) in 2 views. Row 7, holotypic vertebra MSM-41-Taunsa, armor bone MSM-42-Taunsa, proximal ulna MSM43-Taunsa, proximal humerus MSM-44-Taunsa and bone fragment MSM-45-Taunsa; referred Egg MSM-48-Taunsa in 3 views. Row 8, referred tooth impression in rocks; tooth in 2 views and 2 armour bones. Scale black or white digit is $1 \mathrm{~cm}$; for row 5 scale bar is 26 $\mathrm{cm}$; and for row 7 , photo 1 , scale is $30 \mathrm{~cm}$. 
Gomphotherium buzdari share with Proboscidean on the basis of large sized limb elements, age fitness and further common finding of Gomphotherium in host Sulaiman Range. The femur head is circular and directed mostly medio-dorsal. Its tip is slightly wider and expanded then its neck. The head is expanded and raised more than its greater trochanter. There is a depression/notch between trochanter and head. The trochanter raises more than notch and also more thick than adjoining notch. There is a large fossa or shallow depression in the anterior part of proximal femur. There is a small rise in the posterior of proximal femur (close to laterally transverse mid). The distal part of femur is massive, thick and forms its two condyles. The tibia is slender and proximal part is elongated. The fibular fossa on one side and ridge on another side can be observed. There is a thin oval cavity in centre cross section observed at its preserved end (Figure 4). Proboscidean like Gomphotherium, Trilophodon, Bunolophodon and Dinotherium along with other mammals were common in the Miocene-Pliocene of Sulaiman basin.

\section{Eucrocodile from Taunsa-Gulki Area, South Punjab}

Systematic paleontology of Asifcroco retrai is as follow:

Crocodyliformes;

Eucrocodiles (Eusuchian);

Crocodilidae;

Asifcroco [14];

Asifcroco retrai [14];

(Figure 4).

Asifcroco retrai new genus and new species of a fresh water riverine eucrocodile based on holotypic partial right maxilla (with 3 teeth alveoli) and postcranial remains like vertebrae, armor bone, proximal ulna, proximal humerus and bone fragment, and referred egg (Figure 4) collected from the Oligocene ferruginous terrestrial conglomeratic bed of Oligocene Chitarwata Formation of Vihowa Group in Taunsa-Gulki section of Dera Ghazi Khan District, South Punjab [14]. Genus name Asifcroco honors M. Asif Malkani who partially supported this discovery and the visit of Mahoi-Zin, Taunsa-Gulki and Sata post sections of Taunsa area. Species name is after Retra town of Tehsil Taunsa, District Dera Ghazi Khan (D. G. Khan). Fossils are hosted in the museum of Geological Survey of Pakistan, Quetta. Asifcroco retrai shares with Crocodilidae Eucrocodiles on the basis of large, thick, subcircular to oval alveoli and each alveolus have medially/laterally pneumatic elongated fenestrae, pitted armour plate, and on the basis of age and size. Asifcroco retrai characterized by thick and robust maxillary ramus, large internal pneumatic cells above the jaw ramus (in maxilla) like the Induszalim bala, large sized 3 teeth alveoli, anteroposteriorly elongated pneumatic fenestrae on sides of alveoli, same transverse width of alveoli, tight contacted or slightly overlapped nature of teeth alveoli, opisthocoelous vertebra and dorsal groove on ulna for the attachment of ulnar condyle of distal humerus. 
The preserved thick and robust jaw ramus has three large subcircular to oval teeth alveoli which are tightly contacted and slightly overlapped. The maxillary ramus has pneumatic contact on medial and lateral sides of alveoli. The larger alveolus is subcircular $2 \mathrm{~cm}$ in diameter. The second alveolus is circular with 1.5 $\mathrm{cm}$ diameter. The third teeth alveolus is oval having $2 \mathrm{~cm}$ anteroposterior width and 1.5 transverse width. Three continuous teeth are tightly contacted and slightly overlapped in Asifcroco retrai while these are not tightly contacted and also not overlapped in Asiatosuchus. Its centrum is opisthocoelous type having ball on anterior and concave cavity/coel in the posterior. Its ulna have dorsal groove to set humerus (Figure 4). The armour is represented by pitted plate. Further the three eggs are collected, one relatively large egg (Figure 4) may belongs to crocodiles while other small eggs (or egg like) may belong to birds/ snake/lizard. This small egg like material may be osteoderms or coprolite of Buzdartherium baluchithere rhinoceros.

\section{Pterosaurs from the Latest Maastrichtian of Pakistan}

Systematic Paleontology of Saraikisaurus minhui is as follows:

Pterosauria;

Pterodactyloidea;

Saraikisauridae [15];

Saraikisaurus [15];

Saraikisaurus minhui [15];

(Figure 4).

Saraikisaurus minhui new genus and species based on dentary, collected from Topkinwa 16 locality in the latest Maastrichtian Vitakri Lameta Formation of Fort Munro Group, Barkhan district, Balochistan. Fossil is hosted in the museum of Geological Survey of Pakistan, Quetta. Genus Saraikisaurus named after the local language Saraiki. Species name $S$. minhui honors the Prof. Dr. Min Huh of Korea. The closeness of the sockets of Saraikisaurus minhui matches with the pterosaur fossil from the Cretaceous of India [16] which is being referred to it. Saraikisaurus minhui shared with Pterodactyloidea as beak like light, thin, spongy, slender and elongated dentary ramus showing large pterosaur. Saraikisaurus minhui characterized as closeness of teeth and a few overlapped while most of the coeval pterosaurs have far spaced teeth on mandibles and jaws.

Description is as follows. Teeth are anteroposteriorly long and transversely compressed, oval to suboval, heterodont, very close to each other and mostly overlapped and obliquely oriented having direction from anterolaterally to medioposteriorly. The slender partial dentary ramus length is $5.8 \mathrm{~cm}$, height is $2 \mathrm{~cm}$ and width is about $1 \mathrm{~cm}$. The first tooth on preserved dentary beak ramus is 6 $\mathrm{mm}$ anteroposteriorly and $4 \mathrm{~mm}$ transversely wide, the second tooth is $8 \mathrm{~mm}$ anteroposteriorly and $4 \mathrm{~mm}$ transversely wide, the third tooth is $6 \mathrm{~mm}$ anteroposteriorly and $4 \mathrm{~mm}$ transversely wide, the fourth tooth is $7 \mathrm{~mm}$ anteroposteriorly and $4 \mathrm{~mm}$ transversely wide, the fifth tooth is $9 \mathrm{~mm}$ anteroposteriorly and 5 
$\mathrm{mm}$ transversely wide, the sixth tooth is small in size and may showing replacement tooth, the tooth seven is $4 \mathrm{~mm}$ anteroposteriorly and $3 \mathrm{~mm}$ transversely wide and the eight tooth is $6 \mathrm{~mm}$ anteroposteriorly and $4 \mathrm{~mm}$ transversely wide. These measurements reveal that the transverse widths are mostly constant and also half of anteroposteriorly length. All the teeth crown are eroded. Closeness of the sockets represents a large number of teeth in Saraikisaurus minhui. The teeth central cavity and peripheral bone are dominantly exposed as cross section. The closeness of sockets and teeth of Saraikisaurus minhui differ from the Cretaceous pterosaurs from Cretaceous of Eastern England [17], Cearadactylus atrox [18] from the Early Cretaceous of Brazil, Jianchangnathus robustus [19] from middle Jurassic to Early Cretaceous of Lioning China, pterosaur oval to suboval/subcircular teeth from mid Cretaceous of Brazil [20], and lower Cretaceous of Brazil [21], while the size of teeth of Saraikisaurus minhui matches with the above mentioned pterosaurs. Saraikisaurus minhui is a toothed pterosaur supporting the criteria that the toothed pterosaurs continued upto end Cretaceous mass extinction. Further three or four elongated footprints (but not certain) of Anmolpakhi alleni pterosaurs are also found with the latest Maastrichtian titanosaur manus footprint found from the Sur Muzghai site ( $\mathrm{pl}$ see detail in the following subtitle 14.3).

\section{Plesiosaur from Khuzdar District, Balochistan}

Systematic Paleontology of Zahrisaurus kilmoolai is as follows:

Reptilia;

Plesiosauria;

Zahrisaurus new genus;

Zahrisaurus kilmoolai new species;

(Figure 5).

Zahrisaurus kilmoolai, a new genus and new species of plesiosaur or marine reptile, based on holotypic trunk body with ribs MSM-99-K (Figure 5). This body cross section is found in the upper part of Latest Permian-Jurassic Chiltan Limestone of Sulaiman Group from Chotok type locality of Kharzan-Moola area, Khuzdar district, Balochistan. The genus Zahrisaurus honored the host Zahri tribe of Balochistan and saurus mean lizard. The species name $Z$. kilmoolai honored the host Kil Locality of Kharzan area and Moola River which generally flows from west to east and drops its load into Indus River. The holotypic specimen is housed in the museum of Geological Survey of Pakistan, Quetta. The vertebral column and ribs impressions are well preserved (Figure 5). Z. kilmoolai is diagnosed as plesiosaur being broad bodied marine reptiles while ichthyosaurs are streamlined bodied marine reptiles and further by marine limestone as habitat. The autapomorhies include the double track type vertebral column with widely spaced ribs. The vertebral column is double row pitted structures. The double track of vertebral column having thin central boundary with elongated lensoid shape structures. The lateral track type belts have oval shaped structures 
trended posterolaterally. The ribs are resistant structures. The ribs are separated from each other with internal $0.5-1 \mathrm{~cm}$ separation. The ribs orientation show broad bodied animal like plesiosaur instead of streamlined bodied of ichthyosaurs.

\section{Paleo Fishes from Pakistan}

A few fishes are reported here. A possible silicified tooth (Figure 5) of fish or mammal or snake found from the $1 \mathrm{~kg}$ stream coarse sand sized sediments (studied under microscope) collected from the Latest Cretaceous terrestrial Vitakri Lameta Formation of Bara section, Laki Range, Jamshoro District, Sindh.

Systematic Paleontology of Muzaffarabadmachli abbottabadi is as follows:

Fishes;

Agnatha;

Muzaffarabadmachli new genus;

Muzaffarabadmachli abbottabadi new species;

(Figure 5).

Muzaffarabadmachli abbottabadi, a new genus and new species of small sized Agnatha or jawless fish, based one side of body cross section with parallel spines MSM-1-Muzaffarabad (Figure 5) found in the fragmentary dolomitic limestone of Cambrian Abbottabad Formation which is now located in the concrete chip of lawn floor (just south of the steps of door of eastern room) of Tariq Abbassi house (then temporarily hired office of Geological Survey of Pakistan), 130 D, street 16, upper Chattar, Muzaffarabad, Azad Kashmir. Genus Muzaffarabadmachli honored the host Muzaffarabad town and machli is Urdu/Saraiki word with meaning fish. Species name M. abbottabadi honored the host Cambrian Abbottabad dolomitic limestones. M. abbottabadi shares with Agnatha fish by a limb cross section with parallel, coarse and straight ribs/spines. The number of thick segments directed lateroposteriorly (not laterally) is an autapomorphy of Muzaffarabadmachli abbottabadi. The straight ribs/spines are about $2.8 \mathrm{~cm}$. The marine environment is deduced from the deposition of host dolomitic limestone of Cambrian Abbottabad formation which is widely exposed in Abbottabad, Muzaffarabad and Tattapani Kotli areas. This Muzaffarabadmachli abbottabadi Cambrian fish fossils from Pakistan results on Cambrian explosion and seems to be close to Haikouichthys. The total preserved one limb length is $10 \mathrm{~cm}$. Each segment is about $0.3 \mathrm{~cm}$ wide and $3 \mathrm{~cm}$ long and all are parallel and directed lateroposteriorly backward and form the broad body plan.

Systematic Paleontology of Kahamachli harrandlundi is as follows:

Fishes;

Kahamachli new genus;

Kahamachli harrandlundi new species;

(Figure 5).

Kahamachli harrandlundi new genus and new species of freshwater large catfish based on impression (Figure 5) on the Maastrichtian Vitakri Lameta sandstone 


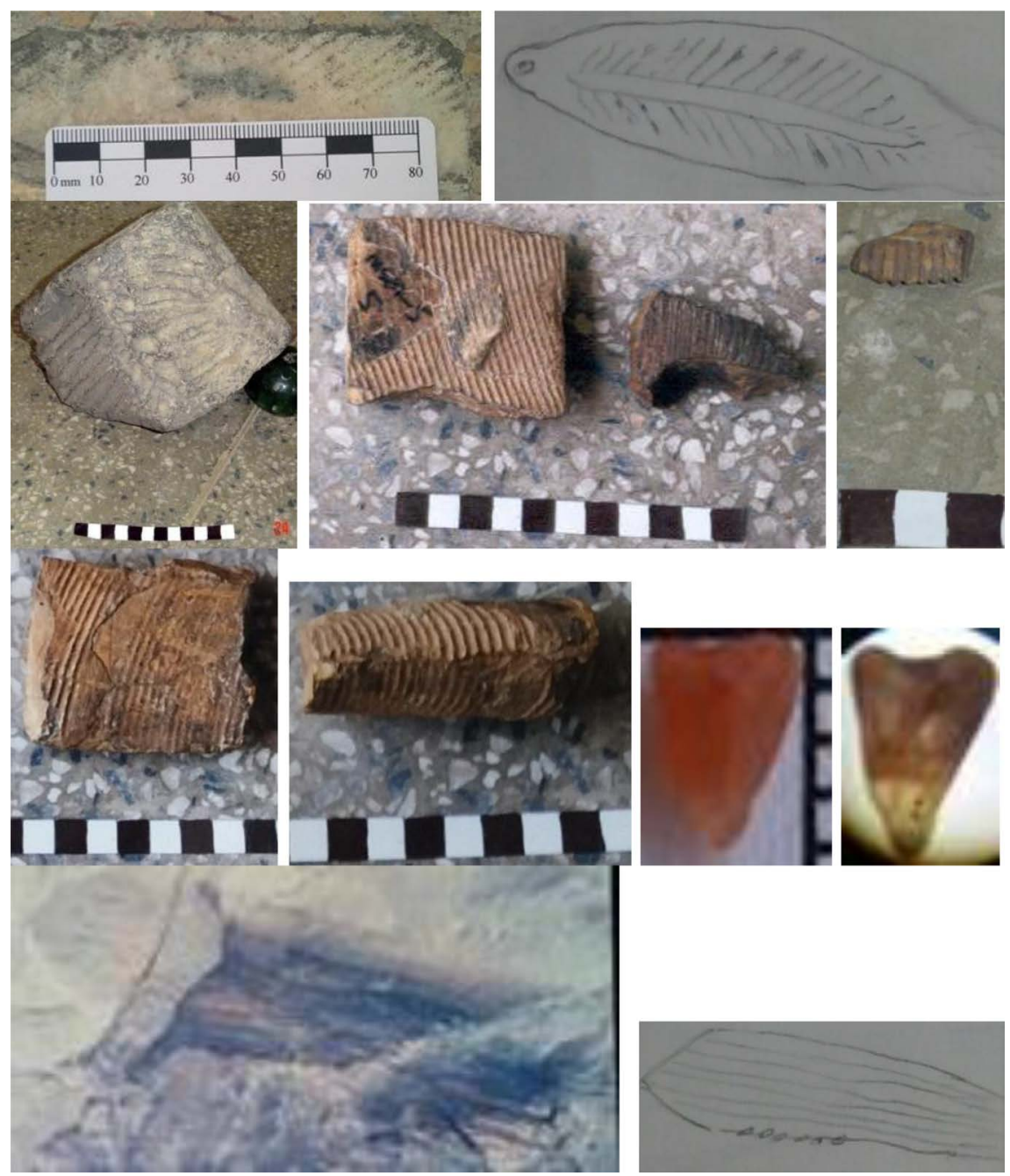

Figure 5. Row 1, Muzaffarabadmachli abbottabadi body limb (MSM-1-Muzaffarabad) of a Cambrian basal Agnatha (jawless) fish. Row 2, Zahrisaurus kilmoolai body (MSM-99-K) a plesiosaur; Karkhimachli sangiali holotype body MSM-1062-K and referred partial limbs MSM-1063-K, MSM-1064-K. Row 3, Karkhimachli sangiali holotype body MSM-1062-K in 2 views; a possible silicified tooth (MSM-1-Laki Bara) of fish or small mammal or snake. Row 4, a lower jaw with some teeth impression of catfish Kahamachli harrandlundi. Scale each black or white digit is $1 \mathrm{~cm}$.

(uppermost portion of the Pab Sandstone) of Kaha Harrand area of Rajanpur District, South Punjab. Genus Kahamachli honored the host Kaha Rud flows from west to east. Kaha rud comes out at Harrand and Lundi Saidan areas and drops its load into Indus River. Machli in Urdu or Saraiki language mean fish. The species name K. harrandlundi honored the host historic Qila (Fort) of Harrand and Lundi after Lundi Saidan town near Harrand town. The jaw teeth and subparallel lineation in jaw shares with catfish. The oval obliquely oriented teeth and subparallel fibrous structures seem to be autapomorphy. The jaw depth is about $20-25 \mathrm{~cm}$ and length is about $75-80 \mathrm{~cm}$. The teeth are oval shaped and spaced (not contacted with each other). The teeth trends obliquely as anterolaterally. The jaw has teeth on the upper part and parallel lineation or striations 
are commonly found (Figure 5).

Systematic Paleontology of Karkhimachli sangiali is as follows:

Fishes;

Karkhimachli [13];

Karkhimachli sangiali [13];

(Figure 5).

Karkhimachli sangiali a new genus and new species of small sized cartilaginous fish based on holotypic body cross section with spines and also have referred materials (Figure 5), found as fragmentary in Maastrichtian-Earliest Paleocene strata of Karkh area of Khuzdar, Balochistan [13]. Its shared with small sized cartilaginous or bony Teleostei or holostei fish on basis of slender herringbone cross bedding structures and spines and streamlined body. These herring bone type spines (arc type) trending almost vertically with little posteriorly and convexing laterally is its autapomorphy. The holotypic body cross section is a herring bone type symmetric spines. The lateral spines initially trend ventrolaterally and then trends ventrally downward forming lateral convexities. Body cross section is $4.5 \mathrm{~cm}$ deep and $7 \mathrm{~cm}$ long with maximum transverse width $3 \mathrm{~cm} .4$ or 5 spines are oriented with in $1 \mathrm{~cm}$ on lateral limb. Body transverse thickness is decreasing posteriorly. Central column is thin. The ribs/spines of left and right lateral sides join with each other side by side. The left spines are not joined directly with right side spines but joined side by side. The left spine joined with the space between the right spines and vice versa. Their streamlined and symmetric body shows a successful predator and also point toward the assignment of small ichthyosaurs.

\section{Invertebrates from Pakistan}

Many invertebrates like ammonites and belemnites (Cephalopoda, Mollusca) found in Mesozoic rocks, nautilides, marine and fresh water (oysters, mussels) bivalves, gastropods, echinoids, arthropods, corals, foraminifers (Amoeboid protists, Retaria, Eukaryota) like Nummulites, Assilina, Alveolina, etc found in Cenozoic rocks were reported in many geological maps. Richest occurrence of Nummulites with Assilina and Alveolina in Pakistan are observed in the shelly limestone and shale of Early Eocene Chamalang Group (= Ghazij Group) and Early-Middle Eocene Kahan Group (or previously called Kirthar Formation) southern limb of Gochina syncline of Harnai area (Western Sulaiman foldbelt), Ziarat and Sibbi districts of Balochistan. One ammonite impression MSM-1069Malakhel (Figure 6) was collected from Middle Jurassic Samanasuk Limestone, Malakhel Broach area, Mianwali district, Punjab. This ammonite print was shown to Dr. A.N. Fatmi-an expert paleontologist of Ammonite from Pakistan and he diagnosed as middle Jurassic age. Two pectin type bivalves mollusks (Figure 6) found from Early Eocene Shaheed Ghat Formation of Kharzan area, Mula Zahri Range, Khuzdar, Balochistan, and one Early Paleocene bivalve is figured from Rakhi Gaj ironstone beds (Figure 6) of Fort Munro area, South Pun- 
jab. Many small gastropods with starfish and bivalves were found in the Early Eocene Shaheed Ghat Formation of Kharzan area (on the vicinity of track from Kharzan to Karkh. The large gastropods were found in the Early Eocene Shaheed Ghat Formation of Kasa area of Loralai District and in middle Eocene Drazinda shale of Zamri area of Musakhel District, Balochistan. Mulastar zahri Echinoid or Echinodermata is first described by [13], found from Late Paleocene-Early Eocene strata, Kharzan area, Balochistan. As it is clear from name star, it includes radial pattern beautiful radiating rays. The dorsal tip is surrounded by circular ring type structures. Further radial rays are double track which are confluent at the dorsal and also possibly at the ventral. These star type double lines are formed by fine dotted textures.

\subsection{Moolatrilo chotoki Trilobite Arthropoda from Balochistan}

Systematic Paleontology of Moolatrilo chotoki is as follows:

Arthropoda;

Trilobita;

Moolatrilo new genus;

Moolatrilo chotoki new species;

(Figure 6).

Previously the trilobite arthropod reported from Early Devonian of Chitral [22] which was correlated with Ural and Altai faunas [22]. Here a new Arthropod (segmented body) trilobite Moolatrilo chotoki new genus and new species, based on a typical holotypic body MSM-1076-K (Figure 6) found from the lower part (Permo-Triassic) of Chiltan Limestone of Sulaiman Group of Kil Chotok area of Tehsil Kharzan (Moola river), Khuzdar district, Balochistan, Pakistan. The finding of Moolatrilo chotoki a trilobite extends the age of lower part of Chiltan Limestone or Sulaiman Group upto Late Permian or atleast Permo-Triassic boundary. The genus Moolatrilo honored the host Moola river of Balochistan and trilo for trilobite. The species name $M$. Chotoki honored the host Chotok Locality. Moolatrilo chotoki has preserved 12 chambers. The chamber size is increasing toward head. The maximum length is $20 \mathrm{~cm}$ and width is $13 \mathrm{~cm}$. The width is increasing gradually toward head. Transversely it is divided into three parts like the central, left lateral and right lateral parts (Figure 6). The Chotok is the best and beautiful tourism locality show long, narrow and high gorge formed by Late Permian to Jurassic limestone of Sulaiman Group which host the perennial water fall where water flows from top to down while fishes enjoys to swim upward.

\subsection{Pakiring kharzani Hippurite (Rudist) Bivalve from Pakistan}

Systematic Paleontology of Pakiring kharzani is as follows:

Bivalvia;

Hippuritida;

Pakiring [13]; 
Pakiring kharzani [13];

(Figure 6).

The Hippuritida (also known as rudists) is an extinct monophyletic order of inequivalved, thick-shelled bivalves, which evolved an extraordinary variety of morphologies [23]. Pakiring kharzani (Figure 6) new genus and new species of Hippuritida, Bivalvia are found from the End Cretaceous (Cretaceous-Tertiary boundary) thin laterite/thin rust of Vitakri Lameta Formation (just above the last bed of Latest Cretaceous Pab sandstone) in the Kharzan area (3 km north of Kharzan town), Khuzdar, Balochistan (Western Kirthar Range). The genus Pakiring honors the host country Pakistan and ring meaning circular. The species Pakiring kharzani named after the Kharzan town, the headquarter of Moola Tehsil of Khuzdar district. Pakiring kharzani shared with Hippuritida as inequivalved, thick-shelled bivalves. Pakiring kharzani characterized by ring type thick shell externally ornamented with rugose ropes (thread in ropes) like rises alternated by falls. The holotype of Pakiring kharzani is almost half circular or half ring forming (Figure 6). It is sub ring type, thick-shelled bivalve. It is a rough surface ornamented bivalve with much rope like rises alternated by falls. The holotypic half ring or one valve is about $4.8 \mathrm{~cm}$ long and $2 \mathrm{~cm}$ maximum thick (Figure 6). It's one valve is shown as holotype and many valves are referred. Pakiring kharzani from Pakistan closely related to Magallanesia rutogensis [24] and Pseudovaccinites giganteus major [25] on the basis of outer rings pattern.

\subsection{Pakiwheel vitakri and Pakiwheel Karkhi Nautiloids}

Systematic Paleontology of Pakiwheel vitakri is as follows:

Mollusca;

Nautiloidea;

Pakiwheel [13];

Pakiwheel vitakri [13];

(Figure 6).

Pakiwheel vitakri Nautiloids Mollusca is first described by [13]. It is stocky type nautiloids MSM-1072-V (Figure 6). It is found just after the CretaceousTertiary (K-T) boundary in Sangiali Formation (of Earliest Paleocene age) close to east of Vitakri town (Bor locality), Barkhan District, Balochistan. Its holotypic shell maximum length is $15 \mathrm{~cm}$ and maximum width is $9.5 \mathrm{~cm}$. Its width is relatively slightly low and depth is proportionally higher than the Pakiwheel karkhi. Its suture lines are not straight. The more depth here is considered stocky.

Systematic Paleontology of Pakiwheel karkhi is as follows:

Mollusca;

Nautiloidea;

Pakiwheel [13];

Pakiwheel karkhi [13];

(Figure 6).

Pakiwheel karkhi Nautiloids is first described by [13]. It is slender nautiloid 


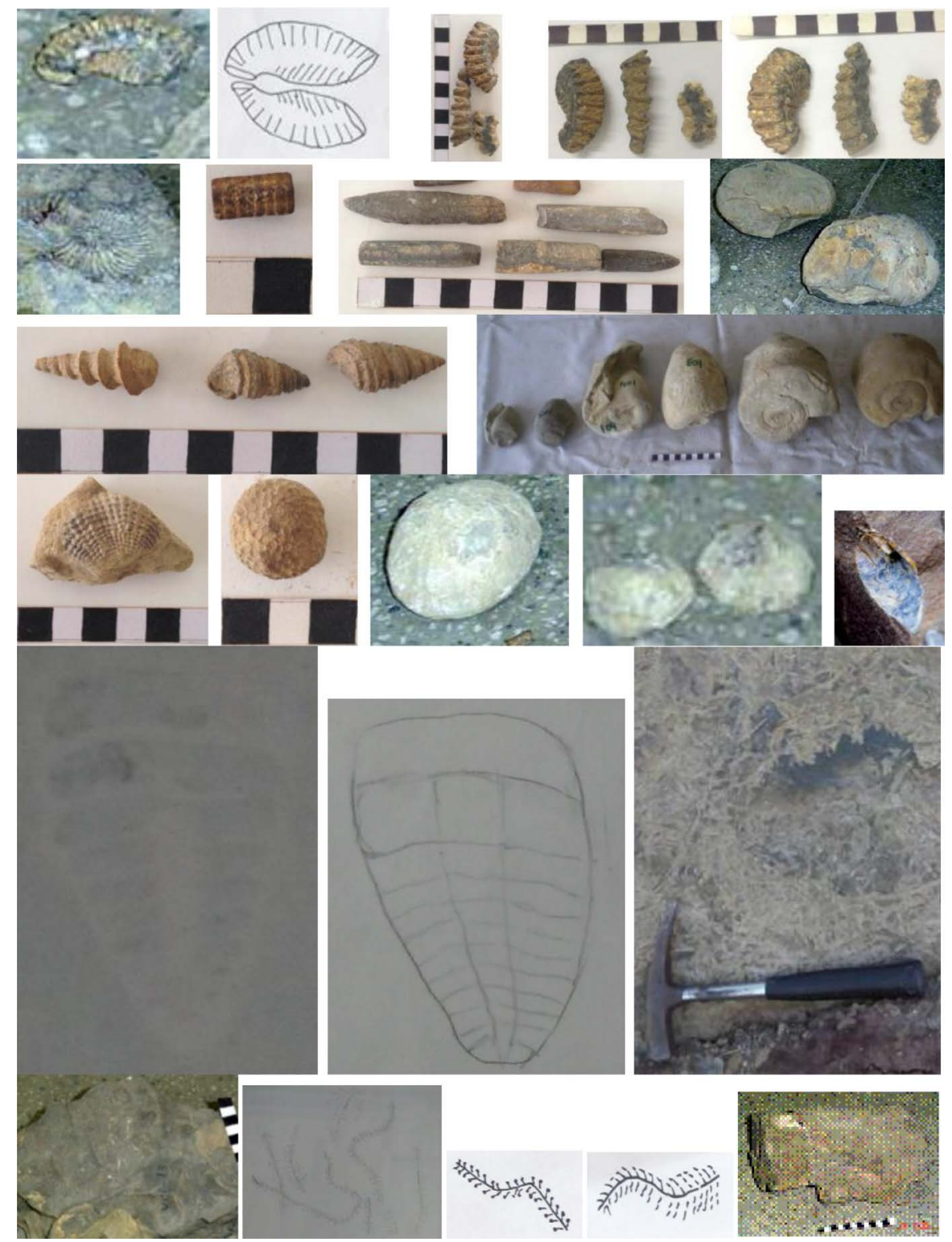

Figure 6. Invertebrate fossils. Row 1, Pakiring kharzani a hippurite /rudist bivalve from Cretaceous-Paleogene boundary. Row 2, p1, 2, Jurassic ammonite impressions; p2 Cretaceous belemnites; and p3 Early Paleocene nautiloids (Pakiwheel karkhi upper and $\mathrm{Pa}$ kiwheel vitakri, lower). Row 3, Eocene gastropods. Row 4, p1 brachiopod; p2 coral or cone; p3 Early Eocene Mulastar zahri starfish/echinoid; p4, 2 Early Eocene bivalves; p5 Early Paleocene bivalve. Row 5, Permo-Triassic boundary Moolatrilo chotoki a trilobite (image and line drawing); and latest Cretaceous spongy algae. Row 6, p1,2, many impressions of Early Paleocene two centipedes; p3, Nisaukankoil beakeri have short legs with large and robust terminal ungual; p4, Phailawaghkankoil derabugti have relatively long legs with large number of phalanges' p5, Baradarakht goeswangai a thick stem MSM-158-6 of possibly gymnosperm tree. Scale each black or white digit is $1 \mathrm{~cm}$.

found in green mudstone of volcanic origin (Deccan volcanic) of Early Paleocene Sangiali Formation of Sangiali Group (= Khadro formation of Ranikot Group), five kilometer east of Karkh town, Khuzdar District. Its holotypic shell maximum length is $13 \mathrm{~cm}$ and maximum width is $8.8 \mathrm{~cm}$. Its width is relatively 
high and depth is proportionally low than the Pakiwheel vitakri. Its less depth here is considered slender. Its suture lines are not straight.

\subsection{Two New Centipedes Arthropods from Balochistan}

Two new centipedes Chilopoda arthropods are being described.

Systematic Paleontology of Nisaukankoil beakeri is as follows:

Arthropoda;

Chilopoda;

Nisaukankoil new genus;

Nisaukankoil beakeri new species;

(Figure 6).

The Nisaukankoil beakeri based on skeletal impressions (Figure 6) found from the muddy sandstone of Earliest Paleocene Rakhi Gaj Formation of northern plunge of Siah Koh anticline, a boarder peak area of Nisau, Kohlu district and Beakar-Phailawagh, Dera Bugti District, Balochistan. Genus name Nisaukankoil honor the host Nisau area of Mari tribe and Kankoil is Saraiki word mean centipedes/millipedes. Species name $N$. beakeri honored the host Beaker area of Bugti Masoori tribe. A sample MSM-Vit-13 of about $20 \mathrm{~cm}$ in dia included both new taxa impressions, housed in the museum of Geological Survey of Pakistan, Quetta. Impression show symmetrical structures. The segments seem to be relatively more and it may increase from 30. The legs of Nisaukankoil beakeri have relatively small legs. The legs of Nisaukankoil beakeri have large and robust terminal ungual on small legs. Many associated skeletal impressions found on the collected specimen. The legs of Nisaukankoil beakeri are relatively short and have less number of phalanges than associated Phailawaghkankoil derabugti another centipede which have relatively long legs and also large number of phalanges. Nisaukankoil beakeri is differentiated on relatively small legs and robust distal ungual from Phailawaghkankoil derabugti another associated centipede which have long legs and alternating slender and robust ungual, it means one leg has slender and other leg has robust/stocky ungual and alternation continues.

Systematic Paleontology of Phailawaghkankoil derabugti is as follows:

Arthropoda;

Chilopoda;

Phailawaghkankoil new genus;

Phailawaghkankoil derabugti new species;

(Figure 6).

The Phailawaghkankoil derabugti based on skeletal impressions (Figure 6) found from the muddy sandstone of Earliest Paleocene Rakhi Gaj Formation of northern plunge of Siah Koh anticline, a boarder peak area of Nisau, Kohlu district and Beakar-Phailawagh, Dera Bugti District, Balochistan. Genus name Phailawaghkankoil honored the host Phailawagh area of Bugti Masoori tribe, Phailawagh Tehsil, Dera Bugti district, Balochistan and Kankoil is Saraiki word 
mean centipedes/millipedes go to ear (kan in Urdu and Saraiki is for ear). The species name $P$. derabugti honored the Bugti tribe of Balochistan. The Phailawaghkankoil derabugti (Figure 6) has alternating slender and stocky distal unguals. Impression show symmetrical structures. The segments seem to be relatively more and it may increase from 30. The legs of Phailawaghkankoil derabugti have relatively large legs. Many associated skeletal impressions of both are also found on the collected specimen. The legs of Phailawaghkankoil derabugti centipede which have relatively long legs and also large number of phalanges while the legs of Nisaukankoil beakeri are relatively short and have less number of phalanges.

\section{Cretaceous Flora from Balochistan}

Systematic Paleontology of Baradarakht goeswangai is as follows:

Planta;

Gymnosperm;

Baradarakht [13] [14];

Baradarakht goeswangai [13] [14];

(Figure 6).

A wood fossil of large tree Baradarakht goeswangai [13] [14] (after Bara means big and long, Darakht mean tree, host Goeswanga Pass area) is found from the Latest Cretaceous (Maastrichtian) Pab Formation (sandstone with negligible shale) of Goeswanga Pass area of Dhaola Range, Barkhan District, Balochistan [13] [14] [26]. It is a cross section of about $20 \mathrm{~cm}$ in diameter (Figure 6) is fibrous and belongs to main trunk of tall tree. The Kingri coal of Vitakri Lameta Formation may be formed from ferns, angiosperms, gymnosperm, etc. Further the algae and spongy network in thin muddy bed (Figure 6) of Vitakri Lameta Formation was observed in the Sur Muzghai Musafarpur site, Qila Saifullah, Balochistan which is also the host of Pashtosaurus zhobi stocky titanosaur footprints.

\section{Footprints and Tracks of Dinosaurs from Pakistan}

Footprints and tracks of stocky titanosauriforms or basal titanosaurs, and two groups of titanosaurian sauropods, small and large theropod dinosaurs were found from the Mesozoic strata of Pakistan so far.

\subsection{Footprints and Tracks of Titanosauriforms or Basal Titanosaurs Confronted by a Large Theropod Found from the Late Jurassic of Malakhel Area, Pakistan}

Trackways of the titanosauriforms (basal titanosaurs or ornithischian) Malakhelisaurus mianwali [27] [28] confronted by a theropod Samanadrinda, found (Figure 7) from the Late Jurassic (150 - $145 \mathrm{Ma}$, few beds below Jurassic-Cretaceous boundary) uppermost Samanasuk Limestone of Baroch Nala, Malakhel area, Mianwali District, Punjab. The tracks pattern shows three parallel trackways 
(Figure 7) indicating a herd. The trackways have a relatively wide gauge (internal trackway width of $0.4 \mathrm{~m}$ ), asymmetric D shaped manus (about $50 \mathrm{~cm} \times 70$ $\mathrm{cm}$ ) without unguals (autapomorphy of titanosaurs), a large circular symmetric pes with five digits (about $1.3 \mathrm{~m} \times 1.3 \mathrm{~m}$ ) which have large oval anteriorly directed toes on digits II, III, IV and reduced outer digits I and V, and feeble $\mathrm{W}$-shaped heel. The distinctive toe impressions clearly indicate three portions with a central oval-shaped ungual which is enveloped by a sole cushion of about $5 \mathrm{~cm}$ width or thickness, anteriorly encased by a broad reversed U-shaped hoof (Figure 7). The heteropody ratio is 1:4.5. Based on the gauge of the trackway, the hip height is estimated at $4-5 \mathrm{~m}$. Trackmakers steps made depressions by compressing cohesive calcareous mud which extruded on the sides. Later on filled by clayey mud. During diagnosis these rocks became hard which is thrusted and exposed by tectonics and erosion.

\subsection{Footprints and Tracks of Stocky and Slender Titanosaurs Found from the Latest Cretaceous Strata of Pakistan}

Footprints of the stocky titanosaur Pashtosaurus zhobi [29] [30] were found from the Latest Cretaceous Vitakri Lameta sandstone beds of Sur Muzghai Locality, opposite Musafarpur Thana, Qila Saifullah district, Zhob division, Balochistan. The first trackway shows left and right pes and manus, and the second trackway shows left and right manus (glided) and right pes (Figure 7). Third trackway has minor indication. The ichnite indicates a herd movement, a relatively narrower gauge $(0.20-0.25 \mathrm{~cm}$ internal trackway width), asymmetric D-shaped manus ( $50-55 \mathrm{~cm} \times 70-75 \mathrm{~cm}$ ) without claws (autapomorphy of titanosaurs), and a giant circular symmetric pes with five digits $(1.27 \mathrm{~m}$ long and $1.28 \mathrm{~m}$ wide), with distinctive large oval anteriorly directed toes (all along the front edge) on digits II, III and IV, and reduced outer digits I and V, and well developed W-shaped heel. The central oval ungual is enveloped by a fleshy sole cushion which is anteriorly encased by a U-shaped hoof. The central digit III is inserted in a forward position which creates a $\mathrm{W}$-shaped heel like in extant camels. One manual imprint shows marks of D-shaped metacarpals I, II, III, IV and V. The heteropody ratio is about 1:4.5. The footprints shape matches with the Late Jurassic Malakhel site. The tracks are referred to titanosaurs rather than to stegosaurs. These footprints are very interesting show D-shaped manus affinity to titanosaurs and large circular pes with large oval ungual and anteriorly covered by hoof show affinity to large thyrophoran ornithischian like stegosaurs and hadrosaurs. Titanosaurs have a symmetric five digits pes with toes on central digits II, III, IV and reduced outer digits I and V without toes, while stegosaurs and hadrosaurs have a symmetric pes with only three digits. The pes of titanosaurs is very large while hadrosaurs and stegosaurs have a triangular pes of moderate size. Unguals are full oval in titanosaurs, and half oval and posteriorly blunted in stegosaurs and hadrosaurs. Titanosaurs have a five digits manus without claws while stegosaurs and hadrosaurs have a five digits manus with two 
unguals (Peter Galton, pers. comm.). Trackmakers steps made depressions by compressing cohesive sandy mud which extruded on the sides. Later on filled by thin clay and then thick sand. During diagnosis the sand formed sandstone and clay formed shale, which are thrusted later on by tectonics and exposed by erosion. Further one D-shaped manus of Pashtosaurus zhobi found in level 2 shows clear impressions of five separated metacarpals (Figure 7). The skin impression found in freshly natural cast formed by filled sand in footprint of the most advanced titanosaur Pashtosaurus zhobi excavated from this site. This sole skin impression reveals tubercles, pits, wrinkles, whorl, loop and contoured textures (Figure 7).

The natural cast of pes footprint of Dgkhansaurus maarri new genus and species based on footprint (Figure 7) is a slender titanosaur found from the latest Cretaceous upper part of Pab Formation (=Vitakri Lameta Formation) of Maarri peak locality, Rajanpur district, Dera Ghazi Khan Division, South Punjab. The Dgkhansaurus is pronunciated as D. G. Khan. Saurus. This genus is named on the name host Dera Ghazi Khan (D. G. Khan) Division and species name established honor the host locality namely Maarri. This pes cast was discovered by Nasir Somro [31]. The pes of Dgkhansaurus maarri is relatively long and thin, slender and it consists of sickle shaped unguals (on digit I, II, III, IV) (Figure 7). While digit V is reduced and has reduced or no ungual. The Dgkhansaurus maarri have slender and laterally directed toes or unguals while in some other cases but outside Pakistan have slender and anteriorly directed toes or unguals. Trackmakers steps made depressions by compressing cohesive sandy mud which extruded on the sides. Later on filled by sand. During diagnosis the sand formed sandstone, which are thrusted later on by tectonics and upper beds having cast of footprints exposed by erosion.

There are two types of pes unguals and pes outlines of footprints showing slender and stocky titanosaurs. The slender titanosaurs are represented by elongated pes with relatively small-sized sickle-shaped unguals (resemble to sauropod saurischians), and the stocky titanosaurs are represented by rounded or circular pes with relatively large-sized oval-shaped anteriorly directed unguals (resemble to sauropod saurischians but also differentiated). This hypothesis of two groups of titanosaurs is also assisted and verified by bone fossil records especially large-sized oval-shaped rugose ungual bone fossils reported from Pakistan. Like these large oval and rugose unguals (previously as oval osteoderms) were also reported from Malawi, Argentina and India. Now it needs finding of complete pes bones. Dgkhansaurus maarri is a derived slender titanosaur, while Pashtosaurus is stocky titanosaur and Malakhelisaurus is stocky titanosauriforms.

\subsection{Footprints of Pterosaurs from Sur Muzghai Site, Zhob Division, Balochistan, Pakistan}

The footprints of Anmolpakhi alleni flying reptile pterosaurs (Figure 7) found 
on level 2 (third bed just below Pashtosaurus zhobi titanosaur ichnotype bed) of Sor Muzghai locality, Musafar Pur Thana area, Qila Saifullah District, Zhob division, Balochistan Province, Westernmost Sulaiman basin. This ichnite is hosted by the latest Cretaceous Vitakri Formation (upper part of Pab sandstone). The pterosaur footprints are associated with asymmetric D shape manus footprint of Pashtosaurus zhobi titanosaur. Manus and pes footprints of Anmolpakhi alleni are recorded. Genus name Anmolpakhi derived from Urdu and Saraiki word Anmol mean "can not be purchased", while Pakhi in Saraiki language mean flying animal/ birds. The species name A. alleni is after Mr. Nicholas Allen British Journalist which helped a lot for the preparation of 3-D models and preservation of Level 5 ichnotype of Pashtosaurus zhobi from this site. The ichnite of Anmolpakhi alleni is located at $30^{\circ} 57^{\prime} 36^{\prime \prime}$ North and $69^{\circ} 08^{\prime} 24^{\prime \prime}$ East in situ in Sor Muzghai site. The pterosaur footprints are about $20-30 \mathrm{~cm}$ long and $8-10$ $\mathrm{cm}$ wide representing hind and fore limb footprints. The pterosaur footprints are parallel with each other. These tracks match closely with pterosaur footprints from the Cretaceous of South Korea. These are found only about one meter width of small exposure of sandstone bed, further excavation reveal better results. The depth of footprints/tracks is very small showing light weight pterosaurs (Figure 7).

\subsection{Trackways of Large and Small Theropod Dinosaurs from the Late Jurassic Strata of Malakhel Area, Pakistan}

The Samanadrinda surghari [27] [28] large theropod trackway including 5 footprints in a single trackway (Figure 7) confronted by a herd of Malakhelisaurus mianwali titanosauriforms (early titanosaurs or may be ornithischian) were found from the Late Jurassic (150 - $145 \mathrm{Ma}$ ) upper successions of Samanasuk Limestone of Baroch Nala, Malakhel area, Mianwali District, Punjab. Limestone dips $52^{\circ}$ west and strike north $50^{\circ}$ east. The trackway pace and stride and straight alignment of pes print reveal a running large bodied theropod attacked obliquely on a herd of Malakhelisaurus mianwali. This site reveals the very large theropod moved and attacked as solitary. The measurement of the first preserved left footprint shows following analysis. Very Large $(72 \mathrm{~cm}$ long; $60 \mathrm{~cm}$ broad) tridactyl footprint have digit length ratios III/II $=1.45$ and III/IV $=1.1$, respectively. The length to width ratio is about 1.2. Phalangeal pads visible in digit II are two, in digit III are three, and in digit IV are four. Toes thick, sharply tapered, digit III is slightly larger than digit IV, while digit III is considerably larger than digit II. It means digit III and digit IV are subequal. Divarication angle of digits II-IV is $50^{\circ}$. On comparison with [32] data, the Samanadrinda surghari footprints characters and ratios are different. Samanadrinda may be an ancestor of ceratosaur abelisauroids while Himalayadrinda is the ancestor of noasaurids. Samanadrinda surghari divarication angle about $50^{\circ}$ are close to Anomoepus sp. The footprints of Samanadrinda from Pakistan are larger than giant theropod footprint from the Early Jurassic of Poland [33] and also larger 
than Indian theropod footprints [34]. Applying [35] revised formula of $\mathrm{H}=4.586$ $\mathrm{L}$, the height upto hip is $3.3 \mathrm{~m}$ and applying [36] formula $H=4 \mathrm{~W}$, the height become $2.4 \mathrm{~m}$. In average height is $2.85 \mathrm{~m}$. It belongs to a biped that has over 2.5 $\mathrm{m}$ height at the hip and $10-12 \mathrm{~m}$ long. Footprints formation process is as follows. The theropod stepped on a thick cohesive calcareous mud layer, its foot sinking to the top part of an underlying calcareous mud layer, producing a negative relief. The calcareous mud was squeezed out sidewise. Later clayey mud layer filled the footprints depression and other succession continued. Diagenesis turned the calcareous mud into limestone and the mud layer into shale. Shale and upper sequences eroded after tectonic uplift. The footprints on hard beds remained preserved and exposed after erosion of upper beds by tectonic uplift which tilted host bed more than $50^{\circ}$.

$400 \mathrm{~m}$ southward from the site of Malakhelisaurus mianwali titanosauriforms confronted by a Samanadrinda surghari theropod ichnotype, two close tracks of a couple of Himalayadrinda potwari [14] small bodied theropods (Figure 7) found from the middle Jurassic (170 - $160 \mathrm{Ma}$ ) Samanasuk limestone of Baroch Nala, Malakhel area, Mianwali District, Punjab. The host limestone bed is few beds below the Samanadrinda (+Malakhelisaurus) host bed. Limestone dips $52^{\circ}$ west and strike north $50^{\circ}$ east. The tracks of Himalayadrinda potwari was about $20 \mathrm{~m}$ high from nearby ground. The convergence of two tracks of small theropods shows interaction behavior. These tracks are very significant for early evolution and diversification of small theropods. This site reveals that smaller theropod moved as herd or at least a couple while large theropod moved as solitary. The tridactyle footprints are small (approximately $15 \mathrm{~cm}$ long; $12 \mathrm{~cm}$ broad) with the ratio of digit III/digit II $=1.4$ and the ratio of digit III/digit IV $=1.0$. The length to width ratio is about 1.2. Toes slender, sharply tapered, digit III and digit IV are subequal while digit III is considerably larger than digit II. The divarication angle of digits II - IV $=c .70^{\circ}-90^{\circ}$. The last toe or claw turned inward. According to comparison with [33] data, this Himalayadrinda is unique small theropod. Reference [37] mentioned interdigital angle upto $50^{\circ}$ of theropod footprints from Brazil but Himalayadrinda from Pakistan have angle upto $90^{\circ}$ (Figure 1). While [37] mentioned interdigital angle upto $80^{\circ}$ of footprints which is close to Himalayadrinda footprints. This study reveals that the Himalayadrinda potwari (divarication angle of digits II - IV $=c .70^{\circ}-90^{\circ}$ ) is the ancestor of noasaurs theropods while Samanadrinda surghari (divarication angle of digits II - IV $=c .50^{\circ}$ ) is the ancestor of abelisauroid theropods. Applying [35] revised formula of $\mathrm{H}=4.586 \mathrm{~L}$ and [36] formula $H=4 \mathrm{~W}$, the general height of Himalayadrinda is about $0.5 \mathrm{~m}$. It belongs to a biped that has $0.3-0.5 \mathrm{~m}$ height at the hip and 1.0 to $1.5 \mathrm{~ms}$ long. This close affinity of Himalayadrinda small theropods with Brazil (South America) like titanosaurs and mesoeucrocodiles again shows paleobiogeographic affinity with South America. This close affinity is due to common Gondwanan early seed radiations and heredity resulted at Early Cretaceous. Trackmakers steps and digits made depressions by compressing cohesive 


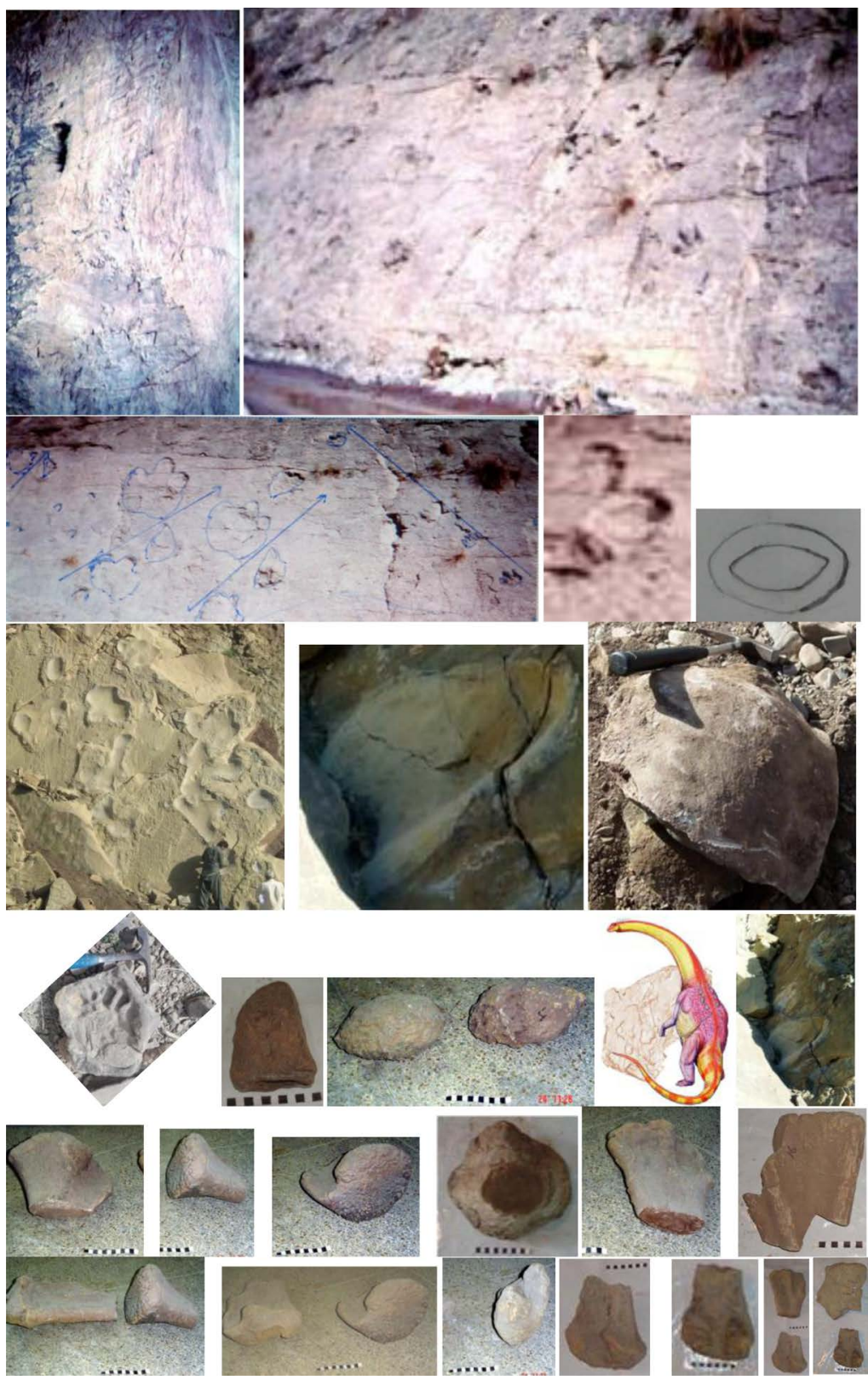

Figure 7. Row 1, photo (p) 1, tracks of a couple of Himalayadrinda potwari small theropods; Row 1, p2 and Row 2, p 1, trackways/tracks of a herd of Malakhelisaurus titanosauriforms confronted by a Samanadrinda theropod. p 2, 3, ungual print (photo and line drawing) of Malakhelisaurus which revealed well preserved three parts like central oval ungual bone mark, surrounded by sole cushion and anterior half arc of hoof. Row 3, p1, Pashtosaurus zhobi stocky titanosaur tracks; p 2, a manus impression of Pashtosaurus which consists of five metacarpal impressions; $\mathrm{p} 3$, a natural cast of Pashtosaurus footprint revealed sole skin impressions as pits and contoured structures. Row 4, p 1, natural cast of slender track of Dgkhansaurus maarri titanosaur; p 2, sickle shaped ungual of slender titanosaur; p 3, 2 large oval ungual (or osteoderm) of stocky titanosaur; p 4, model of stocky Pashtosaurus prepared by cooperation of Nick Allen British Journalist and Dr. Dmitry Bogdanov Russian Paleoartist; p 5, parallel tracks of Anmolpakhi alleni pterosaur with a manus of titanosaur. Row 5, 6, four types of tibiae of poripuch titanosaurs (2 diversified stocky gspsaurids and 2 diversified slender tibia pakisaurids) found from Pakistan. Scale: each black or white unit is $1 \mathrm{~cm}$. 
calcareous mud which extruded on the sides. Later on filled by calcareous clayey mud. During diagnosis these rocks became hard which is thrusted later on by tectonics and exposed by erosion.

\section{Comparison of Recognized Four Titanosaur Taxa from Indo-Pakistan Subcontinent with Four Titanosaur Taxa of Madagascar}

Indo-Pakistan titanosaurs were reported from the latest Maastrichtian (67 - 66 Ma) Vitakri Lameta Formation [38]. References [39] [40] recognized four titanosaur taxa from India. On the basis of diverse cranial, vertebral and limb materials from Pakistan, the reference [41] also recognized four coexisting titanosaur taxa such as Gspsaurus pakistani [42] (including a mid caudal of Antarctosaurus) the thick lense shaped proximal tibia bearing medium bodied Gspsaurinae; and Saraikimasoom vitakri [41] (including two caudals and a tibia of Titanosaurus blanfordi) the subcircular proximal tibia bearing small bodied Saraikimasoominae gspsaurids, and Pakisaurus balochistani [43] (including one vertebra of Titanosaurus indicus; one robust straight tooth of Titanosaurus rahioliensis) the thin bone tibia bearing the large sized pakisaurid; and filled the gaps in Isisaurus colberti like femur, tibia, fibula and metacarpal. All these four recognized taxa of Indo-Pakistan have synapomorphies of poripuch [38] the most derived titanosaurs which have procoelous all the anterior, middle and distal caudals except the first caudal in stocky taxa [38]. There was longstanding issue and controversy that how many valid titanosaur existed in the latest Cretaceous of Indo-Pakistan. Now it became certain, consistent and confident by finding of four types of tibiae from Pakistan (especially proximal tibiae-unique gifts in global world). Four type of tibiae (Figure 7) including two diverse stocky tibiae like rounded proximal tibia of Saraikimasoom with equal transverse and anteroposterior width, and anteroposteriorly lense shaped proximal tibia of Gspsaurus, and two diverse slender tibiae with low transverse thickness like transversely thin proximal tibia of Pakisaurus with lateral fibular ridge as arc shaped ended just below the cnemial crest, and transversely thin proximal tibia of Isisaurus with lateral fibular ridge as parallel/subparallel to anterior profile of cnemial crest and shaft. These four types of tibiae and associated diverse cranial and postcranial elements are discovered from Pakistan belonging to four taxa of Indo-Pakistan subcontinent [44], solved the longstanding issue of number of titanosaur's taxa from Indo-Pakistan. Besides titanosaurs, two large theropods $\mathrm{Vi}$ takridrinda [45] and Vitakrisaurus [45] [46] and two large sized mesoeucrocodiles Induszalim [45] [47] and Pabwehshi [48], and pterosaur Saraikisaurus minhui were also discovered from Pakistan.

The Maastrichtian Vitakri Lameta Formation (terrestrial red muds, and sandstone) of Indo-Pakistan correlated with the Maastrichtian Maevarano Formation (terrestrial red muds, and sandstone) of Madagascar. Further four coexisting latest titanosaurs hosted by Vitakri Lameta Formation also match closely with four latest titanosaurs hosted by Maevarano Formation. Further the finding of 
diverse 4 types of caudal vertebrae and diverse 4 types of tibiae and other diverse skeletal elements from Pakistan belong to four poripuch titanosaur taxa which provided the facility for correlation and comparison with Malagasy titanosaur fossils. This interpretation is consistent with the four coexisted latest titanosaurs from Indo-Pakistan peninsula. From Madagascar, the titanosaurian three taxa identified on the basis of diverse caudal vertebrae and fourth titanosaur taxon identified on the basis of slender tibia with lateral fibular articular ridge forms arc shape and ended just below the cnemial crest. Because four types of tibia associated with typical vertebrae from Pakistan. First, the large caudal vertebra UCB 92829 of Titanosaurus madagascariensis [49] from Madagascar matches closely with Saraikimasoom of Indo-Pakistan peninsula due to strong ventral reduction of caudal. Second, the other small caudal vertebra UCB 92305 of Titanosaurus madagascariensis [49] from Madagascar may be close to Isisaurus (Sulaimanisaurus) from Indo-Pakistan due to almost square shape (although slightly broad) and no ventral reduction. Third, the caudal vertebra FMNH PR 2209 of Rapetosaurus [50] from Madagascar show close resemblance to Gspsaurus from Indo-Pakistan landmass due to slightly tall and ventrally reduced caudal vertebra. Fourth, the transversely narrow slender tibia with arc shaped lateral fibular condylar ridge ended just below the cnemial crest, humerus and teeth of Rapetosaurus [50] from Madagascar matches closely to Pakisaurus from South Asia. This shows the dual affinity (chimera) of fossils of Titanosaurus madagascariensis [49] and also the dual affinity (chimera) of fossils of Rapetosaurus krausei [50].

Indo-Pakistan subcontinent now occupied and covered South Asia while the present research revealing previous contact with Gondwana is consistent with Indo-Pakistan paleobiogeographic hypothesis. The latest Cretaceous titanosaurian sauropods of Indo-Pakistan show paleobiogeographic affinity to Madagascar, revealing earliest Cretaceous contact of Indo-Pakistan landmass with Madagascar, instead of present contact with Asia. Indo-Pakistan started northward journey at Early Cretaceous (135 Mya) and continued journey as island during most of the Cretaceous. Indo-Pakistan plate first time collided with Asia during the latest Cretaceous (67 - $66 \mathrm{Mya}$ ) just before or at the time of Cretaceous-Paleogene mass extinction. This northward migration from southern hemisphere to northern hemisphere of earth via equator is responsible for the geological, tectonics, paleontological, evolutionary and morphological changes in Indo-Pakistan landmass.

\section{Conflicts of Interest}

The author declares no conflicts of interest regarding the publication of this paper.

\section{References}

[1] Linnaeus, C. (1758) Systema Naturae per regna tria naturae, secundum classis, ordines, genera, species cum characteribus, differentiis, synonymis, locis. Tenth Edi- 
tion, Vol. 1, Laurentii Salvii, Stockholm, 824 p. https://doi.org/10.5962/bhl.title.542

[2] Brisson, A.D. (1762) Regnum Animale in Classes IX Distributum Sive Synopsis Methodica. Edito altero auctior. Theodorum Haak, Leiden, 294 p.

[3] Flower, W.H. (1883) On the Arrangement of the Orders and Families of Existing Mammalia. Proceedings of the Zoological Society of London, 1, 178-186.

[4] Cope, E.D. (1868) Second Contribution to the History of the Vertebrata of the Miocene Period of the United States. Proceedings of the Academy of Natural Sciences of Philadelphia, 20, 184-194.

[5] Malkani, M.S., Dhanotr, M.S.I., Latif, A. and Saeed, H.M. (2013) New Remains of Basilosauridae-The Giant Basal Whale, and Baluchithere-The Giant Rhinoceros Discovered from Balochistan Province (Pakistan). Sindh University Research Journal (Science Series), 45, 177-188.

[6] Gingerich, P.D., Arif, M., Bhatti, M.A., Anwar, M. and Sanders, W.J. (1997) Basilosaurus Drazindai and Basiloterus Hussaini, New Archaeoceti (Mammalia Cetacea) from the Middle Eocene Drazinda Formation, with a Revised Interpretation of Ages of Whale-Bearing Strata in the Kirthar Group of the Sulaiman Range, Punjab (Pakistan). Contribution from Museum of Paleontology, University of Michigan. 30, 55-81.

[7] Gingerich, P.D. and Zouhri, S. (2015) New Fauna of Archaeocete Whales (Mammalia, Cetacea) from the Bartonian Middle Eocene of Southern Morocco. Journal of African Earth Sciences, 111, 273-286.

https://doi.org/10.1016/j.jafrearsci.2015.08.006

[8] Kellogg, R. (1936) A Review of the Archaeoceti. Carnegie Institution of Washington Publications, Washington, Vol. 482, 1-366.

[9] Zalmout, I.S., Mustafa, H.A. and Gingerich, P.D. (2000) Priabonian Basilosaurus isis (Cetacea) from the Wadi Eshshallala Formation: First Marine Mammal from the Eocene of Jordan. Journal of Vertebrate Paleontology, 20, 201-204. https://doi.org/10.1671/0272-4634(2000)020[0201:PBICFT]2.0.CO;2

[10] Harlan, R. (1834) Notice of Fossil Bones Found in the Tertiary Formation of the State of Louisiana. Transactions of the American Philosophical Society, 4, 397-403. https://doi.org/10.2307/1004838

[11] Owen, R. (1848) On the Archetype and Homologies of the Vertebrate Skeleton. van Hoorst, London. https://doi.org/10.5962/bhl.title.118611

[12] Gray, J.E. (1821) On the Natural Arrangements of Vertebrose Animals. Monthly Journal and Review, 15, 296-310.

[13] Malkani, M.S. (2014) Records of Fauna and Flora from Pakistan; Evolution of Indo-Pakistan Peninsula. Abstract Volume of 2 nd Symposium of IGCP 608 "Cretaceous Ecosystem of Asia and Pacific”, Tokyo, 4-6 September 2014, 165-168.

[14] Malkani, M.S. (2015) Dinosaurs, Mesoeucrocodiles, Pterosaurs, New Fauna and Flora from Pakistan. Geological Survey of Pakistan, Information Release No. 823, $1-32$.

[15] Malkani, M.S. (2013) New Pterosaur from the Latest Cretaceous Terrestrial Strata of Pakistan. Abstract Book of 9 th Symposium on Cretaceous System, Ankara, 1-5 September 2013, 62 .

[16] Dubey, V.S. and Narain, K. (1946) A Note on the Occurrence of Pterosauria in India. Current Science, 15, 287-288.

[17] Unwin, D.M. (2001) An Overview of the Pterosaur Assemblage from the Cambridge Greensand (Cretaceous) of Eastern England. Fossil Record, 4, 189-221. 
https://doi.org/10.5194/fr-4-189-2001

[18] Unwin, D.M. (2002) On the Systematic Relationships of Cearadacty Zus Atrox, an Enigmatic Early Cretaceous Pterosaur from the Santana Formation of Brazil. Fossil Record, 5, 239-263. https://doi.org/10.5194/fr-5-239-2002

[19] Cheng, X., Wang, X., Jiang, S. and Kellner, A.W.A. (2012) A New Scaphognathid Pterosaur from Western Liaoning, China. Historical Biology, 24, 101-111. https://doi.org/10.1080/08912963.2011.635423

[20] Elias, F.A., Bertini, R.J. and Medeiros, M.A.A. (2007) Pterosaur Teeth from the Laje do Coringa, Middle Cretaceous, São Luís-Grajaú Basin, Maranhão State, NrthNortheastern Brazil. Revista Brasileira de Geociências, 37, 668-676. https://doi.org/10.25249/0375-7536.20073744760668676

[21] Veldmeijer, A.J., Signore, M. and Meijer, H.J.M. (2005) Description of Two Pterosaur (Pterodactyloidea) Mandibles from the Lower Cretaceous Santana Formation, Brazil. Deinsea, 11, 67-86.

[22] Pascoe, E.H. (1959) A Manual of the Geology of India and Burma. Vol. II, Inddia Govt Press, Calcutta, 44-88.

[23] Skelton, P.W. (2018) Part N, Volume 1, Chapter 26A: Introduction to the Hippuritida (Rudists): Shell Structure, Anatomy, and Evolution. Treatise Online 104, 1-37.

[24] Rao, X., Skelton, P.W., Sha, J., Cai, H. and Iba, Y. (2015) Mid-Cretaceous Rudists (Bivalvia: Hippuritida) from the Langshan Formation, Lhasa Block, Tibet. Papers in Palaeontology, 1, 401-424. https://doi.org/10.1002/spp2.1019

[25] Toucas, A. (1904) Études sur la classification et l'évolution des Hippurites, deuxième partie. Société géologique de France, Paléontologie, Mémoires 30, 65-128.

[26] Malkani, M.S. and Sun, G. (2016) Fossil Biotas from Pakistan with Focus on Dinosaur Distributions and Discussion on Paleobiogeographic Evolution of Indo-Pak Peninsula. Global Geology, 19, 230-240.

[27] Malkani, M.S. (2007) Trackways Evidence of Sauropod Dinosaurs Confronted by a Theropod Found from Mid Jur. Samana Suk Limestone of Pakistan. Sindh University Research Journal (Science Series), 39, 1-14.

[28] Malkani, M.S. (2008) Marisaurus (Balochisauridae, Titanosauria) Remains from the Latest Cretaceous of Pakistan. Sindh University Research Journal (Science Series), 40, 55-78.

[29] Malkani, M.S. (2014) Titanosaurian Sauropod Dinosaurs from the Latest Cretaceous of Pakistan. Abstract Volume of 2 nd Symposium of IGCP 608 "Cretaceous Ecosystem of Asia and Pacific", Tokyo, 4-6 September 2014, 108-111.

[30] Malkani, M.S. (2018) Titanosaurian Osteoderms and Manus and Pes Shape Revealed from Ichnological and Skeletal Records of South Asia (Indo-Pak Peninsula). Proceedings of 13th Mesozoic Terrestrial Ecosystems, 21-23 July 2018, Volume 2018, 74-76.

[31] Malkani, M.S., Somro, N. and Arif, S.J. (2018) A New Pes Footprint of Sauropod Dinosaur Discovered from the Latest Cretaceous of Pakistan. Researchgate.net, Research, 1 p.

[32] Olsen, P.E., Smith, J.B. and McDonald, N.G. (1998) Type Material of the Type Species of the Classic Theropod Footprint Gen Era Eubrontes, Anchisauripus, and Grallator (Early Jurassic, Hartford and Deerfield Basins, Connecticut and Massachusetts, USA). Journal of Vertebrate Paleontology, 18, 586-601. https://doi.org/10.1080/02724634.1998.10011086

[33] Gierlinski, G., Niedzwiedzki, G. and Pienkowski, G. (2001) Gigantic Footprint of a 
Theropod Dinosaur in the Early Jurassic of Poland. Acta Paleontologica Polonika, 46, 441-446.

[34] Pienkowski, G., Branski, P., Pandey, K.D., Schlogl, J., Alberti, M. and Fursich, F.T. (2015) Dinosaur Footprints from the Thaiat Ridge and Their Palaeoenvironmental Background, Jaisalmer Basin, Rajastan, India. Volumina Jurassica, 13, 17-26.

[35] Gonzalez Riga, B.J. (2011) Speeds and Stance of Titanosaur Sauropods: Analysis of Titanopodus Tracks from the Late Cretaceous of Mendoza, Argentina. Anais da Academia Brasileira de Ciências (Annals of Brazilian Academy of Sciences), 83, 1-12. https://doi.org/10.1590/S0001-37652011005000002

[36] Lockley, M.G. (1986) A Guide to Dinosaur Tracksites of the Colorado Plateau and American Southwest. University of Colorado at Denver, Geology Department Magazine, Special Issue 1, $56 \mathrm{p}$.

[37] Fernandes, M.A., Ghilardi, A.M., Carvalho, I.S. and Leonardi, G. (2010) Pegadas de dinosaurs theropoda do paleodeserto botucatu (Jurassico Superior-Cretaceous Inferior) da bacia do Parana (Theropod Dinosaurs Footprints of the Botucatu Paleodesert (Upper Jurassic-Lower Cretaceous) from Parana Basin. Paleontologia: Cenários de Vida, 4, 609-621.

[38] Malkani, M.S. (2019) Cretaceous Stratigraphy of Pakistan. Open Journal of Geology, 9, 671-673. https://doi.org/10.4236/ojg.2019.910071

[39] Huene, F.V. and Matley, C.A. (1933) Cretaceous Saurischia and Ornithischia of the Central Provinces of India. Paleontologia Indica, 21, 1-74.

[40] Jain, S.L. and Bandyopadhyay, S. (1997) New Titanosaurid (Dinosauria: Sauropoda) from the Late Cretaceous of Central India. Journal of Vertebrate Paleontology, 17, 114-136. https://doi.org/10.1080/02724634.1997.10010958

[41] Malkani, M.S. (2019) Smallest Titanosaur from Indo-Pakistan Landmass. Open Journal of Geology, 9, 627-630. https://doi.org/10.4236/ojg.2019.910059

[42] Malkani, M.S. (2019) Medium Sized Stocky Titanosaur from South Asia. Open Journal of Geology, 9, 631-634. https://doi.org/10.4236/ojg.2019.910060

[43] Malkani, M.S. (2019) Large Titanosaur from Indo-Pakistan Peninsula. Open Journal of Geology, 9, 635-638. https://doi.org/10.4236/ojg.2019.910061

[44] Malkani, M.S. (In Process) Exploration of First Bone of Dinosaur from Pakistan to Diverse Fauna.

[45] Malkani, M.S. (In Process) Exploration of Latest Theropods, Mesoeucrocodiles and Pterosaurs from Pakistan.

[46] Malkani, M.S. (2019) Vitakrisaurus saraiki Theropod from South Asia. Open Journal of Geology, 9, 643-645. https://doi.org/10.4236/ojg.2019.910063

[47] Malkani, M.S. (2019) Induszalim bala Mesoeucrocodile from Pakistan. Open Journal of Geology, 9, 623-626. https://doi.org/10.4236/ojg.2019.910058

[48] Wilson, J.A., Malkani, M.S. and Gingerich, P.D. (2001) New Crocodyliform (Reptilia, Mesoeucrocodylia) Form the Upper Cretaceous Pab Formation of Vitakri, Balochistan (Pakistan). Contributions from Museum of Paleontology, University of Michigan, 30, 321-336.

[49] Depéret, C. (1896) Note sur les dinosauriens sauropodes et théropodes du Crétacé supérieur de Madagascar. Bulletin de la Société Géologique de France, 24, 176-194.

[50] Curry Rogers, K. (2009) The Postcranial Osteology of Rapetosaurus krausei (Sauropoda: Titanosauria) from the Late Cretaceous of Madagascar. Journal of Vertebrate Paleontology, 29, 1046-1086. https://doi.org/10.1671/039.029.0432 